\title{
Size and time-resolved roadside enrichment of atmospheric particulate pollutants
}

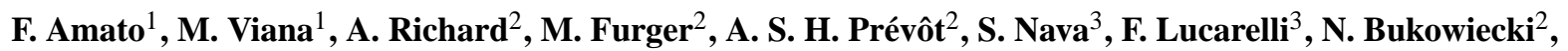 \\ A. Alastuey ${ }^{1}$, C. Reche ${ }^{1}$, T. Moreno ${ }^{1}$, M. Pandolfi ${ }^{1}$, J. Pey $^{1}$, and X. Querol ${ }^{1}$ \\ ${ }^{1}$ Institute of Environmental Assessment and Water Research, Spanish Research Council (IDÆA-CSIC), C/Jordi Girona \\ 18-26, 08034 Barcelona, Spain \\ ${ }^{2}$ Laboratory of Atmospheric Chemistry, Paul Scherrer Institut, 5232 Villigen, Switzerland \\ ${ }^{3}$ National Institute of Nuclear Physics (INFN) and Department of Physics and Astronomy, University of Florence, via \\ Sansone 1, 50019 SestoFiorentino, Italy
}

Received: 2 November 2010 - Published in Atmos. Chem. Phys. Discuss.: 7 January 2011

Revised: 16 March 2011 - Accepted: 22 March 2011 - Published: 29 March 2011

\begin{abstract}
Size and time-resolved roadside enrichments of atmospheric particulate pollutants in $\mathrm{PM}_{10}$ were detected and quantified in a Mediterranean urban environment (Barcelona, Spain). Simultaneous data from one urban background (UB), one traffic (T) and one heavy traffic (HT) location were analysed, and roadside $\mathrm{PM}_{10}$ enrichments (RE) in a number of elements arising from vehicular emissions were calculated. Tracers of primary traffic emissions (EC, $\mathrm{Fe}, \mathrm{Ba}, \mathrm{Cu}, \mathrm{Sb}, \mathrm{Cr}$, $\mathrm{Sn})$ showed the largest REs $(>70 \%)$. Other traffic tracers $(\mathrm{Zr}$, Cd) showed lower but still consistent REs (25-40\%), similar to those obtained for mineral matter resulting from road dust resuspension $(\mathrm{Ca}, \mathrm{La}, \mathrm{Ce}, \mathrm{Ti}, \mathrm{Ga}, \mathrm{Sr}, 30-40 \%)$. The sum of primary and secondary organic carbon showed a RE of $41 \%$, with contributions of secondary OC (SOC) to total OC ranging from $46 \%$ at the HT site, $63 \%$ at the T site, and $78 \%$ in the UB. Finally, other trace elements (As, Co, Bi) showed unexpected but consistent roadside enrichments (23\% up to $69 \%$ ), suggesting a link to traffic emissions even though the emission process is unclear.

Hourly-resolved PM speciation data proved to be a highly resourceful tool to determine the source origin of atmospheric pollutants in urban environments. At the HT site, up to $62 \%$ of fine Mn was attributable to industrial plumes, whereas coarse Mn levels were mainly attributed to traffic. Similarly, even though $\mathrm{Zn}$ showed on average no roadside enrichment and thus was classified as industrial, the hourlyresolved data proved that at least $15 \%$ of coarse $\mathrm{Zn}$ may be attributed to road traffic emissions. In addition, our results indicate that secondary nitrate formation occurs within the
\end{abstract}

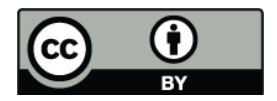

Correspondence to: F. Amato

(fulvio.amato@idaea.csic.es) city-scale, even in the absence of long atmospheric residence times or long-range atmospheric transport processes. Characteristic tracer ratios of road traffic emissions were identified: $\mathrm{Cu} / \mathrm{Sb}=6.8-8.0, \mathrm{Cu} / \mathrm{Sn}=4.7-5.4$ and $\mathrm{Sn} / \mathrm{Sb}=1.5$.

\section{Introduction}

Vehicular traffic is known to be one of the major, if not the largest, sources of atmospheric particulate matter (PM) in the urban environment (Almeida et al., 2005; Viana et al., 2008; EEA, 2009; Gietl et al., 2010; Amato et al., 2009a; Bukowiecki et al., 2010; Amato et al., 2009c). Traffic emissions are generally produced via the exhaust, by abrasion of vehicle parts and by resuspension of material deposited on the roads. These particulates are rich in metallic species and polycyclic aromatic hydrocarbons (PAHs) of known carcinogenicity and with a potential risk to human health (Harrison and Yin, 2000). Several epidemiological studies showed evidence of increasing health risks with proximity to road traffic emissions (Hoffman et al., 2009; Hoek et al., 2001).

However, despite the predominant contribution from vehicular traffic to PM levels in terms of mass, this is not the only emission source of PM present in the urban environment (e.g., industrial emissions, shipping contributions, residential heating systems, etc.). As a result, the origin of heavy metals in the urban aerosol mix may not be ascribed to vehicular traffic only. If effective PM abatement strategies are to be implemented, the contribution from traffic to the levels of these particulates must be discriminated from that originating from other sources. Even though PM source apportionment analyses are widely available in the literature (Bruinen de Bruin

Published by Copernicus Publications on behalf of the European Geosciences Union. 
et al., 2006; Viana et al., 2008; Gietl et al., 2010, and references therein), the vast majority of their results are limited by the time resolution of the input samples, typically 12 or $24 \mathrm{~h}$. However, the impact on PM levels and personal exposure of vehicular traffic as an emission source is evident on an hourly time basis. Consequently, the use of PM speciation data with an hourly time resolution would be strongly recommended for source apportionment studies.

In addition, vehicular traffic is also a significant source of gaseous precursors $\left(\mathrm{NO}_{\mathrm{x}}, \mathrm{CO}\right)$ and, thus, of secondary aerosols (de Gouw et al., 2009). The speed at which oxidation processes take place is strongly dependent on atmospheric and meteorological conditions, with the result that it varies as a function of the geographical region (Jiménez et al., 2009). In the Mediterranean basin, secondary aerosol formation is enhanced due to increased insolation and relative humidity with respect to Northern European regions (Pey et al., 2008). The rate at which secondary aerosol formation takes place determines the spatial variability of these aerosols, and thus their potential health hazards for the population. Consequently, from the air quality monitoring and epidemiological perspectives it is of great interest to assess the formation rate of traffic-derived secondary aerosols within the urban environment.

The present study aims to evaluate the impact on PM chemistry of the emission sources present in the urban environment, with a special focus on vehicular traffic. To this end, the roadside increments in the levels of metals and other trace elements were analysed at three urban environments: one urban background (UB), one traffic (T) and one heavy traffic (HT) site. The emission sources of single elements and species were determined, as well as their enrichment as a function of traffic volume (in the case of traffic-related elements). In addition, speciation data of size segregated PM with an hourly time resolution were analysed at the urban background and heavy traffic sites. Finally, the spatial scale at which secondary aerosol formation takes place is discussed.

\section{Methods}

\subsection{The study area}

Measurements were undertaken in Barcelona within the multidisciplinary DAURE campaign (Determination of the sources of atmospheric Aerosols in Urban and Rural Environments in the western Mediterranean) (Pandolfi et al., 2010, http://cires.colorado.edu/jimenez-group/wiki/ index.php/DAURE). The urban area of Barcelona covers $101 \mathrm{~km}^{2}$ with 1.6 million inhabitants $(4.5$ million in the greater metropolitan area). Such a high population concentration results in one of the highest car densities in Europe, 6100 cars per $\mathrm{km}^{2}$ compared with Milan (4400), Madrid (2300) or Berlin (1400). This makes Barcelona a somewhat typical Mediterranean city in terms of traffic-related PM pollution, suffering both from a high car density and a frequent lack of precipitation. The air quality of the metropolitan area is also affected by a complex topography that plays a key role in the atmospheric dynamics and hence in the dispersion of pollutants (Jimenez et al., 2006). The city of Barcelona is located in a coastal depression enclosed between two river basins hosting several urban agglomerations and numerous industrial clusters: ferrous and nonferrous smelters, cement and asphalt production industries, two power stations and city waste incinerators. In addition to local emissions, African dust outbreaks reach Barcelona in the order of 4-5 days per month increasing the annual $\mathrm{PM}_{10}$ mean by $2-3 \mu \mathrm{g} \mathrm{m}^{-3}$ (Querol et al., 2009; Escudero et al., 2005). Jointly, the urban architecture, characterized by square-blocks with narrow streets, reduces the dispersion of pollutants and the scarce precipitation $(520 \mathrm{~mm}$ as mean from 2003 to 2009, Servei Meteorologic de CatalunyaObservatori Fabra) favours the accumulation and resuspension of particulate matter deposited at ground.

Urbanisation around Barcelona (Spain) accounts also for a high road traffic density from people entering the city from surrounding towns who largely use private transport (47\%). A considerable contribution to traffic density derives from motorcycles and scooters, with a share of $29 \%$ of total vehicles. Moreover, in the province of Barcelona (similarly to the rest of Spain), the number of diesel-powered cars has doubled from 1997 to 2007, and their proportion to the total fleet has also increased (26\% to 43\%) (http://apl.dgt.es/IEST2/).

The traffic volume is concentrated in the Eixample, a commercial and residential square-blocks area where most of the population live and work, with narrow streets inducing high exposure and a canyon effect for the dispersion of pollutants. It covers approximately a third of the total extension of the city. Traffic is intense, typically stop-andgo and with high braking frequency. The busiest road (Diagonal Avenue), crosses the city from NE to SW, with a mean of 106000 vehicles per day (2008). The commercial and touristic harbour is located very close to the city centre, and handles around 13000 ships per year (2008, http: //www.bcn.es/estadistica/catala/index.htm).

PM levels in the urban background reflect the unsatisfactory level of atmospheric pollution. According to earlier studies, the ambient $\mathrm{PM}_{10}$ and $\mathrm{PM}_{2.5}$ concentrations (annual average at urban background: 2003-2006) in Barcelona were in the ranges of $39-42 \mu \mathrm{gPM}_{10} \mathrm{~m}^{-3}$ and $25-29 \mu \mathrm{gPM}_{2.5} \mathrm{~m}^{-3}$ (Perez et al., 2008), exceeding the daily limit value from the European Air Quality Directive 2008/50/EC $\left(50 \mu \mathrm{gPM}_{10} \mathrm{~m}^{-3}\right)$ between 44 and 75 times on average per year (data from Air Quality Monitoring Network). Approximately $80 \%$ of such exceedances are due to anthropogenic PM contributions with high proportions of mineral dust (Perez et al., 2008; Querol et al., 2001a, 2004). 


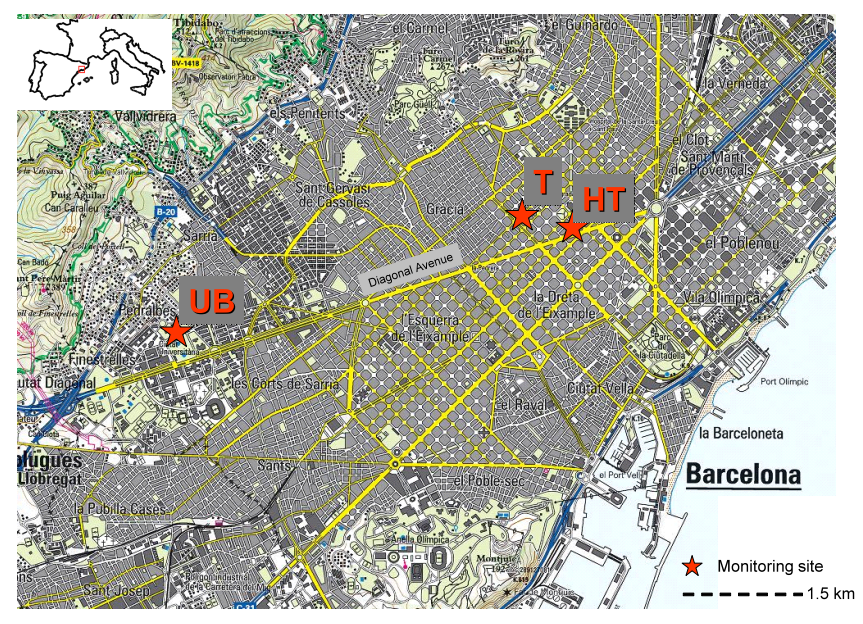

Fig. 1. Study area and monitoring locations.

In the present study, the experiments were carried out in two parallel roads of Eixample and at an urban background site, located $5 \mathrm{~km}$ away from the traffic sites. The HT site was located at Valencia Avenue counting typically 19000 vehicles day ${ }^{-1}$. This is a preferred route from the city centre to the northern exit of the city. Valencia Avenu is a $19 \mathrm{~m}$ wide five-lane road, including a left lane reserved for parking lots. Building height varies between 6 and 7 storeys, making it a street canyon with secondary roads intersecting it perpendicularly (Fig. 1). The $\mathrm{T}$ site was located at Corsega Avenue, a nearby street, parallel and similar to Valencia Avenue, but with less traffic (11000 vehicles day $\left.{ }^{-1}\right)$ and opposite traffic flow. This area was selected due to the fact that traffic flows are unidirectional, parallel to the coast, horizontal, and fairly constant across the whole road, thus it represents a simple scenario for pollutant dispersion. At both roads, mobile laboratory vans were installed on the left parking lane and at the same distance $(25 \mathrm{~m})$ from the closest crossing. Traffic volume decreased markedly from HT to T. Moreover the HT site was the closest to the Diagonal Avenue, the major avenue in Barcelona with a mean traffic volume of 106000 vehicles day ${ }^{-1}$. Therefore the increase in traffic emissions (at HT) is considered to be the only difference in PM emission sources between both study locations. The impact of sources such as industry, regional-scale air mass transport or road works is considered the same at both traffic sites. Conversely, differences are expected in the impact of sources other than road traffic (dust from construction sites, road works, industry, etc.) between the UB site and the two traffic sites. The UB site was located inside a small park (Torre Girona) $500 \mathrm{~m}$ away from a major road and approximately $5 \mathrm{~km}$ west from $\mathrm{T}$ and HT.

\subsection{Air quality measurements}

From 27 February to 2 April 2009 PM sampling was carried out simultaneously at the three sites, with $12 \mathrm{~h}$ cycles (10:00-22:00-10:00 LT) at the urban background site, and $24 \mathrm{~h}$ cycles at the traffic sites (10-10 local time). DIGITEL and MCV high volume samplers $\left(30 \mathrm{~m}^{3} \mathrm{~h}^{-1}\right)$ were collecting $\mathrm{PM}_{10}$ on quartz fibre filters ( $\varnothing 15 \mathrm{~cm}$, Munktell). A total of $140 \mathrm{PM}_{10}$ samples were collected and analyzed following the procedures described by Querol et al. (2001b) to determine concentration of $\mathrm{Al}, \mathrm{Ca}, \mathrm{K}, \mathrm{Mg}, \mathrm{Fe}, \mathrm{Ti}, \mathrm{Mn}, \mathrm{P}, \mathrm{S}, \mathrm{Na}$, $\mathrm{SO}_{4}^{2-}, \mathrm{NO}_{3}^{-}, \mathrm{Cl}^{-}, \mathrm{NH}_{4}^{+}$and 25 trace elements. A section of $1.5 \mathrm{~cm}^{2}$ of the filter was used for the determination of organic carbon (OC) and elemental carbon (EC) by a thermaloptical transmission technique (Birch and Cary, 1996) using a Sunset Laboratory OCEC Analyzer with the EUSAAR2 temperature program (Cavalli et al., 2010). Concentrations were field-blank corrected. After calculating oxides, silica $\left(2.5 \cdot \mathrm{Al}_{2} \mathrm{O}_{3}\right)$ and carbonates $(\mathrm{Ca} \cdot 1.5)$, the remaining 10 $15 \%$ of unidentified mass was attributed to non-C atoms of organic matter and the still remaining structural and adsorbed water by aerosols and/or filter media.

Furthermore, hourly elemental characterization of size segregated PM was performed with hourly resolution at the HT and UB sites continuously during 3 weeks. To this aim a Rotating Drum Impactor (RDI) and a Streaker sampler were installed respectively at UB and HT sites. Full details of these instruments can be found elsewhere (Formenti et al., 1996; Bukowiecki et al., 2009). Briefly, at the UB site a rotating drum impactor (RDI) was used as sampling device (Bukowiecki et al., 2009), collecting hourly aerosol samples in three size ranges $(0.1-1 \mu \mathrm{m}, 1-2.5 \mu \mathrm{m}$ and $2.5-10 \mu \mathrm{m})$. The collected samples were analyzed by synchrotron radiation induced X-Ray fluorescence spectrometry (SR-XRF). The calibration was performed according to the procedure detailed in Richard et al. (2010). At the HT site a Streaker sampler was used, collecting hourly aerosol samples in two size ranges $(0.1-2.5 \mu \mathrm{m}$ and $2.5-10 \mu \mathrm{m})$. The collected samples were analyzed by Particle Induced X-Ray Emission (PIXE, see Chiari et al., 2005 for details).

In both cases X-Ray spectra have been fitted for 20 elements (Al, Si, P, S, Cl, K, Ca, V, Cr, Mn, Fe, Ni, Cu, Zn, $\mathrm{Rb}, \mathrm{Sr}, \mathrm{Zr}, \mathrm{Mo}, \mathrm{Sn}, \mathrm{Ti}$ and $\mathrm{Sb}$ ) and the elemental concentrations were obtained via a calibration curve from a set of thin standards certified within 5\% (Micromatter Inc.). To assure the comparability of PIXE and SR-XRF analysis, concentrations from different size ranges were summed into $\mathrm{PM}_{10}$ levels and then corrected by inter-comparison with the daily concentrations obtained by analysis on filters collected with high volume samplers (with the exception of $\mathrm{Si}$, due to the use of quartz fiber filters). For SR-XRF measurements the correction factors were approximately 1 for $\mathrm{Ca}, \mathrm{Ti}, \mathrm{V}, \mathrm{Mn}$, $\mathrm{Fe}, \mathrm{Cu}, \mathrm{Zn}, \mathrm{Rb}, \mathrm{Sr}, \mathrm{Mo}, \mathrm{Sn}$ and $\mathrm{Sb}$. Al and $\mathrm{Zr}$ were significantly underestimated by SR-XRF and $\mathrm{P}, \mathrm{S}, \mathrm{Cl}, \mathrm{K}, \mathrm{Cr}$ and $\mathrm{Ni}$ significantly overestimated. For PIXE most elements were 
Table 1. Mean levels (of simultaneous data) of $\mathrm{PM}_{10}$ and its chemical measured components (in $\mu \mathrm{g} \mathrm{m}^{-3}$ ) at the heavy traffic (HT), traffic (T) and urban background (UB) sites. Maximum values between the three sites are highlighted in bold. Minimum levels are highlighted in italics. Mean values from 2 March to 2 April. NA: not available. DL: detection limit $\left(\mu \mathrm{g} \mathrm{m}^{-3}\right.$ or $\left.\mathrm{ng} \mathrm{m}^{-3}\right)$ calculated for the whole analytical process ( $24 \mathrm{~h}$ sampling), including standard deviation of blanks.

\begin{tabular}{|c|c|c|c|c|c|c|c|}
\hline & \multicolumn{2}{|c|}{ HT } & \multicolumn{2}{|c|}{$\mathrm{T}$} & \multicolumn{2}{|c|}{ UB } & \multirow[t]{2}{*}{ DL } \\
\hline & Mean & Stdev. & Mean & Stdev. & Mean & Stdev. & \\
\hline $\mathrm{Al}$ & 0.53 & 0.31 & 0.48 & 0.31 & 0.42 & 0.26 & 0.07 \\
\hline As* & 0.8 & 0.2 & 0.7 & 0.3 & 0.7 & 0.3 & 0.1 \\
\hline $\mathrm{Ba}^{*}$ & 44 & 15 & 17 & 14 & NA & NA & 37.1 \\
\hline $\mathrm{Bi}^{*}$ & 1.1 & 0.3 & 0.7 & 0.2 & 0.4 & 0.2 & 0.04 \\
\hline $\mathrm{Ca}$ & 2.1 & 1.2 & 1.6 & 1 & 1.4 & 1 & 0.04 \\
\hline $\mathrm{Cd}^{*}$ & 0.3 & 0.3 & 0.3 & 0.3 & 0.2 & 0.1 & 0.1 \\
\hline $\mathrm{Ce}^{*}$ & 1.3 & 0.4 & 1.1 & 0.5 & 0.7 & 0.3 & 0.3 \\
\hline $\mathrm{Cl}^{-}$ & 1.6 & 0.7 & 1.1 & 0.8 & 1.3 & 0.8 & 0.2 \\
\hline $\mathrm{Co}^{*}$ & 0.4 & 0.2 & 0.3 & 0.1 & 0.2 & 0.1 & 0.04 \\
\hline $\mathrm{Cr}^{*}$ & 17 & 5 & 12 & 6 & 5 & 2 & 1.8 \\
\hline $\mathrm{Cu}^{*}$ & 105 & 27 & 59 & 23 & 28 & 13 & 3 \\
\hline EC & 5.8 & 1.7 & 3.6 & 1.3 & 1.8 & 0.9 & 0.1 \\
\hline $\mathrm{Fe}$ & 2.1 & 0.6 & 1.3 & 0.5 & 0.6 & 0.3 & 0.02 \\
\hline $\mathrm{Ga}^{*}$ & 0.2 & 0.1 & 0.2 & 0.1 & 0.2 & 0.1 & 0.04 \\
\hline $\mathrm{K}$ & 0.4 & 0.2 & 0.3 & 0.2 & 0.3 & 0.2 & 0.02 \\
\hline $\mathrm{La}^{*}$ & 0.4 & 0.2 & 0.4 & 0.2 & 0.3 & 0.2 & 0.1 \\
\hline $\mathrm{Li}^{*}$ & 0.6 & 0.3 & 0.5 & 0.3 & 0.5 & 0.3 & 0.01 \\
\hline $\mathrm{Mg}$ & 0.3 & 0.1 & 0.3 & 0.1 & 0.3 & 0.1 & 0.02 \\
\hline $\mathrm{Mn}^{*}$ & 28 & 9 & 20 & 8 & 15 & 11 & 0.8 \\
\hline $\mathrm{Mo}^{*}$ & 8.4 & 4.3 & 4.3 & 2.6 & 5.5 & 3.3 & 0.01 \\
\hline $\mathrm{Na}$ & 1 & 0.7 & 1.1 & 0.8 & 1 & 0.7 & 0.1 \\
\hline $\mathrm{NH}_{4}^{+}$ & 1.6 & 1.2 & 2.1 & 2.2 & 2.1 & 1.7 & 0.02 \\
\hline $\mathrm{Ni}^{*}$ & 5.9 & 2.4 & 5.2 & 2.8 & 4.6 & 3.1 & 1.2 \\
\hline $\mathrm{NO}_{3}^{-}$ & 5.5 & 3.1 & 6.2 & 3.6 & 4 & 3.5 & 0.1 \\
\hline $\mathrm{OC}^{3}$ & 5.9 & 2.2 & 5.3 & 2.3 & 4.3 & 2.5 & 0.1 \\
\hline $\mathrm{P}$ & 0.03 & 0.02 & 0.02 & 0.01 & 0.02 & 0.01 & 0.01 \\
\hline $\mathrm{Pb}^{*}$ & 11 & 4 & 11 & 6 & 13 & 7 & 0.6 \\
\hline $\mathrm{PM}_{10}$ & 53 & 17 & 46 & 16 & 42 & 17 & NA \\
\hline $\mathrm{Rb}^{*}$ & 1.1 & 0.6 & 0.9 & 0.5 & 0.9 & 0.6 & 0.1 \\
\hline $\mathrm{Sb}^{*}$ & 13.2 & 4 & 7.3 & 3.9 & 2.9 & 1.5 & 0.1 \\
\hline $\mathrm{Se}^{*}$ & 1 & 0.6 & 1 & 0.7 & 0.9 & 0.7 & 0.1 \\
\hline $\mathrm{Sn}^{*}$ & 22 & 6 & 13 & 5 & 6 & 3 & 2.0 \\
\hline $\mathrm{SO}_{4}^{2-}$ & 2.2 & 1.1 & 2.8 & 1.4 & 3.3 & 1.4 & 0.1 \\
\hline $\mathrm{Sr}^{*}$ & 5.8 & 2.6 & 4.6 & 2.5 & 4 & 2.1 & 0.4 \\
\hline $\mathrm{Ti}^{*}$ & 42 & 21 & 34 & 18 & 29 & 15 & 2.1 \\
\hline $\mathrm{U}^{*}$ & 0.1 & 0.05 & 0.08 & 0.05 & 0.13 & 0.07 & 0.01 \\
\hline $\mathrm{V}^{*}$ & 11 & 6 & 10 & 6 & 9 & 6 & 0.2 \\
\hline $\mathrm{Zn}^{*}$ & 87 & 29 & 72 & 36 & 81 & 59 & 31.2 \\
\hline $\mathrm{Zr}^{*}$ & 15 & 2 & 12 & 5 & 12 & 5 & 0.01 \\
\hline
\end{tabular}

* Values in $\mathrm{ng} \mathrm{m}^{-3}$.

corrected by factors around 1 with the exception of $\mathrm{Rb}$ and $\mathrm{Sb}$ that were significantly overestimated.

\section{Results and discussion}

Mean $\mathrm{PM}_{10}$ levels for the entire monitoring period (only simultaneous data), as well as its chemical components, at the three study locations (heavy traffic, HT; traffic, T; ur- ban background, UB) are summarised in Table $1 . \mathrm{PM}_{10}$ levels showed an expected decreasing trend from the heavy traffic environment (HT, $53 \mu \mathrm{g} \mathrm{m}^{-3}$ ) to the traffic site (T, $46 \mu \mathrm{g} \mathrm{m}^{-3}$ ) and the urban background (UB, $42 \mu \mathrm{g} \mathrm{m}^{-3}$ ), which was also observed for the major tracers of primary traffic emissions (e.g., EC, 5.8 at $\mathrm{HT}, 3.6 \mu \mathrm{g} \mathrm{m}^{-3}$ at $\mathrm{T}$, $1.8 \mu \mathrm{g} \mathrm{m}^{-3}$ at UB) but not for $\mathrm{m} \mu \mathrm{g} \mathrm{m}^{-3}$ arkers of secondary aerosols (e.g., $\mathrm{NH}_{4}^{+}, 1.6 \mu \mathrm{g} \mathrm{m}^{-3}$ at $\mathrm{HT}, 2.1 \mu \mathrm{g} \mathrm{m}^{-3}$ at $\mathrm{T}$, $2.1 \mathrm{\mu g} \mathrm{m}^{-3}$ at $\mathrm{UB}$ ). Tracers of industrial/shipping emissions (e.g., Ni, $5.9 \mathrm{ng} \mathrm{m}^{-3}$ at HT, $5.2 \mathrm{ng} \mathrm{m}^{-3}$ at T, $4.6 \mathrm{ng} \mathrm{m}^{-3}$ at UB) did not show any clear trend between the three sites within the uncertainty of the chemical determinations. Carbonaceous aerosols evidenced similar trends to those observed by other authors (Harrison and Yin, 2008), with a large gradient in EC concentrations between the traffic and background sites, but a low gradient in $\mathrm{OC}(5.9,5.3$, and $4.3 \mathrm{ng} \mathrm{m}^{-3}$ ).

\subsection{Roadside enrichments}

Roadside enrichments (REs) due to traffic emissions were calculated for each variable as the ratio between the increased concentrations at the site with higher traffic volume, with respect to the observed concentration, for a given variable:

$\mathrm{RE}_{i}(\%)=\frac{x_{i}^{\mathrm{HT}}-x_{i}^{\mathrm{T}}}{x_{i}^{\mathrm{HT}}} \cdot 100$

where $i$ is a given chemical component (variable) of $\mathrm{PM}_{10}$, $x$ is the concentration of the component $i$, and HT and T are the two study locations for which the concentrations of component $i$ are compared. Roadside enrichments due to traffic emissions were also calculated at the HT and T sites with respect to UB (Table 2). This approach was previously applied by Snyder et al. (2010) and Oliveira et al. (2010).

Two main groups of PM components were differentiated:

- Group I: variables enriched at all the sites with higher traffic volume with respect to the lower traffic volume (all calculated REs $>0$, Table 2). The only exception to this classification was K, with REs $>0$ but included in Group II due to the pattern observed in the scatter plots (Fig. 2a), described in the following section.

- Group II: variables not always enriched at the site with higher traffic volume (REs $>0$ and $<0$ ) (Fig. $2 b$ and Table 2).

Only four variables were considered as exceptions to Groups I and II ( $\mathrm{Al}, \mathrm{NO}_{3}^{-}, \mathrm{V}$ and $\left.\mathrm{Ni}\right)$, and they were classified as Group III (Table 2). A detailed analysis of the nature of these variables is provided in the following section.

Within Group I variables (enriched by traffic emissions), as expected, REs were increasing for all species from $\mathrm{T}$ to HT (in comparison with UB, Table 2). Major enrichments above $35 \%$ of the mass were obtained for $\mathrm{Ba}, \mathrm{Bi}, \mathrm{Ce}, \mathrm{Co}$, $\mathrm{Cr}, \mathrm{Cu}, \mathrm{EC}, \mathrm{Fe}$, mineral matter, $\mathrm{Mn}, \mathrm{OC}, \mathrm{Sb}, \mathrm{Sn}$ and $\mathrm{Ti}$ 

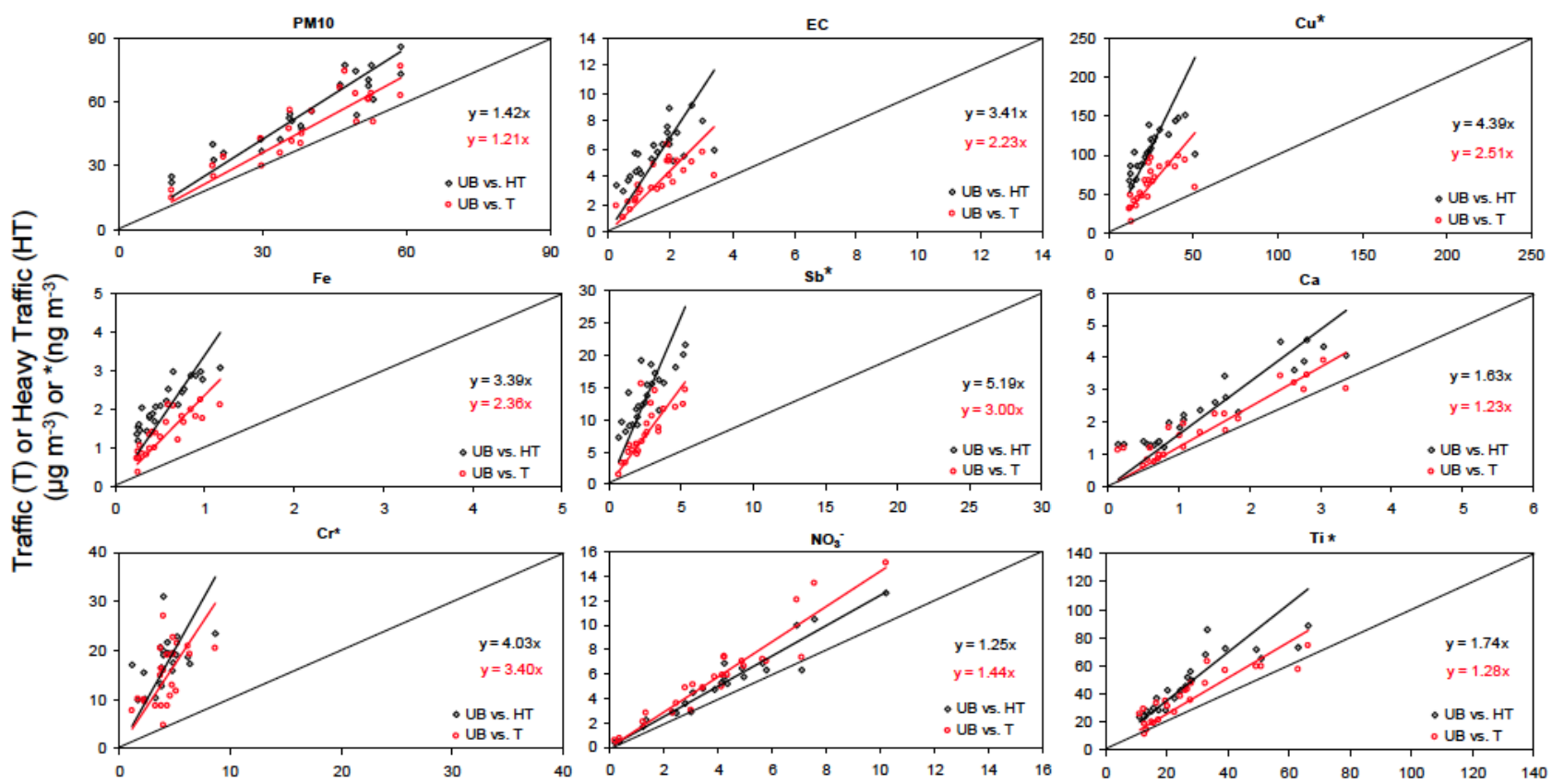

Urban background UB

$\left(\mu \mathrm{g} \mathrm{m}^{-3}\right)$ or * $\left(\mathrm{ng} \mathrm{m}^{-3}\right)$

Fig. 2a. Correlation between the urban background (UB), heavy traffic (HT) and traffic (T) sites, with respect to the urban background (UB), of the mean daily levels of $\mathrm{PM}_{10}$ components showing enrichment due to vehicular traffic emissions (Group I variables).

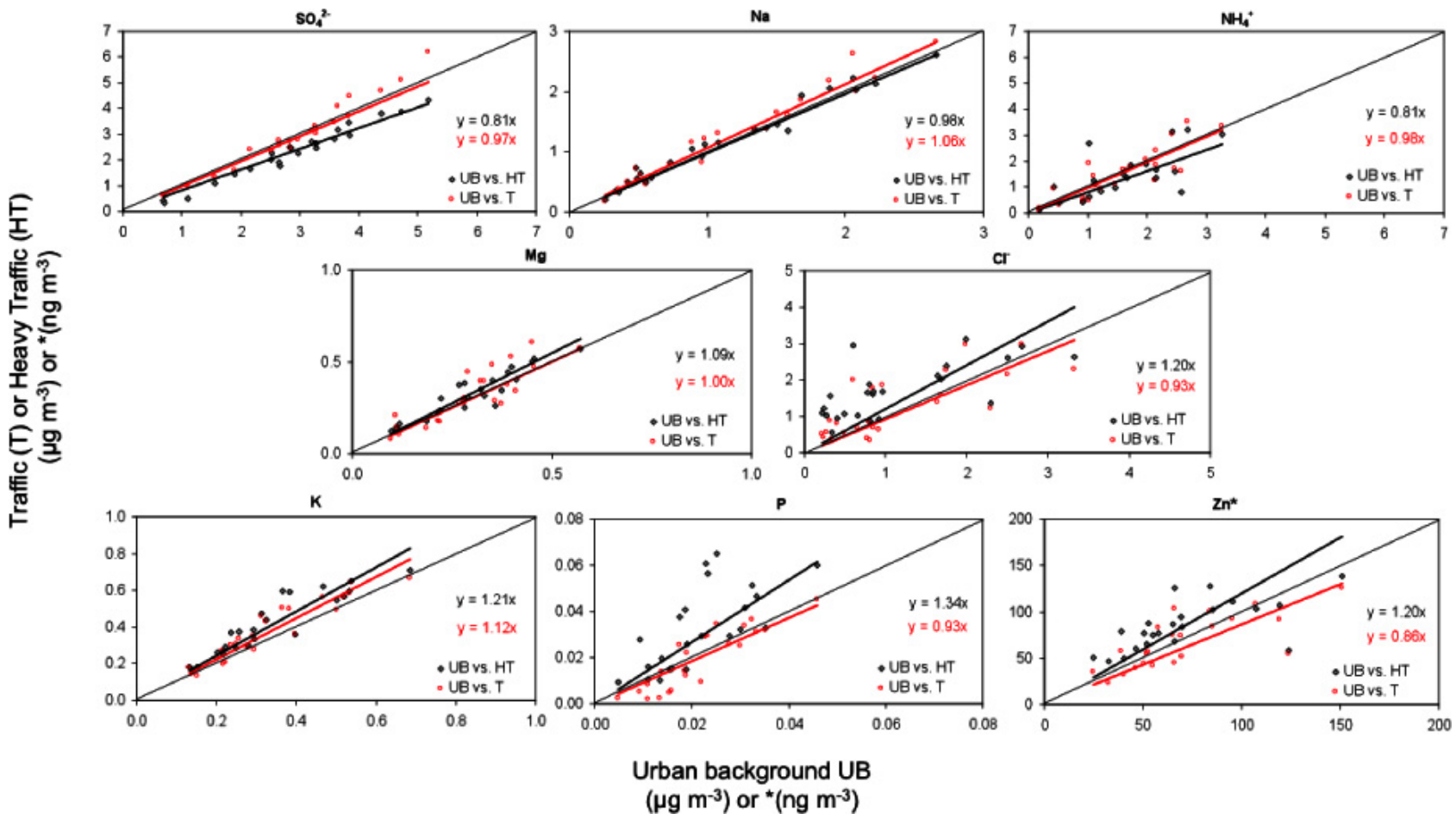

Fig. 2b. Correlation between the heavy traffic (HT) and traffic (T) sites, with respect to the urban background (UB), of the mean daily levels of $\mathrm{PM}_{10}$ components not showing enrichment due to vehicular traffic emissions (Group II variables). 
Table 2. Roadside enrichments $\left(\mathrm{RE}_{\mathrm{PM}_{10}}\right)$ calculated at the heavy traffic and the traffic sites with respect to the urban background (T vs. UB, HT vs. UB), and between both traffic sites (HT vs. T). Group I: variables showing enrichment with higher traffic volume. Group II: variables not showing enrichment with higher traffic volume. Group III: exceptions to Groups I and II variables. NA: not available. OC: organic carbon. EC: elemental carbon. Mineral: sum of mineral components. REs $>35 \%$ are highlighted in bold, and REs $<0$ in italics. Mean values from 2 March to 2 April. Mineral matter was calculated as the sum of directly measured species: $\mathrm{Ca}, \mathrm{Mg}, \mathrm{Fe}, \mathrm{Al}$ and $\mathrm{K}$ (silica and carbonates are not included).

\begin{tabular}{|c|c|c|c|}
\hline & T vs. UB & HT vs. UB & HT vs. T \\
\hline Group I & RE (\%) & $\mathrm{RE}(\%)$ & $\mathrm{RE}(\%)$ \\
\hline As & $12 \%$ & $23 \%$ & $10 \%$ \\
\hline $\mathrm{Ba}$ & NA & NA & $65 \%$ \\
\hline $\mathrm{Bi}$ & $48 \%$ & $69 \%$ & $48 \%$ \\
\hline $\mathrm{Ca}$ & $13 \%$ & $33 \%$ & $13 \%$ \\
\hline $\mathrm{Cd}$ & $32 \%$ & $38 \%$ & $1 \%$ \\
\hline $\mathrm{Ce}$ & $42 \%$ & $50 \%$ & $18 \%$ \\
\hline Co & $33 \%$ & $47 \%$ & $16 \%$ \\
\hline $\mathrm{Cr}$ & $67 \%$ & $75 \%$ & $29 \%$ \\
\hline $\mathrm{Cu}$ & $58 \%$ & $76 \%$ & $50 \%$ \\
\hline $\mathrm{EC}$ & $55 \%$ & $72 \%$ & $41 \%$ \\
\hline $\mathrm{Fe}$ & $57 \%$ & $73 \%$ & $40 \%$ \\
\hline $\mathrm{Ga}$ & $13 \%$ & $29 \%$ & $16 \%$ \\
\hline $\mathrm{La}$ & $28 \%$ & $33 \%$ & $3 \%$ \\
\hline Mineral & $23 \%$ & $40 \%$ & $15 \%$ \\
\hline $\mathrm{Mn}$ & $33 \%$ & $54 \%$ & $33 \%$ \\
\hline OC & $34 \%$ & $41 \%$ & $12 \%$ \\
\hline $\mathrm{PM}_{10}$ & $17 \%$ & $27 \%$ & $11 \%$ \\
\hline $\mathrm{Sb}$ & $65 \%$ & $80 \%$ & $51 \%$ \\
\hline $\mathrm{Sn}$ & $58 \%$ & $75 \%$ & $48 \%$ \\
\hline $\mathrm{Sr}$ & $11 \%$ & $29 \%$ & $16 \%$ \\
\hline $\mathrm{Ti}$ & $18 \%$ & $36 \%$ & $23 \%$ \\
\hline $\mathrm{Zr}$ & $5 \%$ & $26 \%$ & $21 \%$ \\
\hline \multicolumn{4}{|l|}{ Group II } \\
\hline $\mathrm{Cl}^{-}$ & $0 \%$ & $27 \%$ & $-6 \%$ \\
\hline $\mathrm{K}$ & $1 \%$ & $8 \%$ & $5 \%$ \\
\hline $\mathrm{Li}$ & $-3 \%$ & $18 \%$ & $15 \%$ \\
\hline $\mathrm{Mg}$ & $-4 \%$ & $-4 \%$ & $-7 \%$ \\
\hline Mo & $-32 \%$ & $29 \%$ & $45 \%$ \\
\hline $\mathrm{Na}$ & $-7 \%$ & $-10 \%$ & $-1 \%$ \\
\hline $\mathrm{NH}_{4}^{+}$ & $25 \%$ & $5 \%$ & $-30 \%$ \\
\hline$P^{4}$ & $-11 \%$ & $30 \%$ & $23 \%$ \\
\hline $\mathrm{Pb}$ & $-6 \%$ & $-6 \%$ & $5 \%$ \\
\hline $\mathrm{Rb}$ & $-5 \%$ & $14 \%$ & $15 \%$ \\
\hline $\mathrm{Se}$ & $5 \%$ & $5 \%$ & $-2 \%$ \\
\hline $\mathrm{SO}_{4}^{2-}$ & $-5 \%$ & $-29 \%$ & $-22 \%$ \\
\hline $\mathrm{U}^{4}$ & $-73 \%$ & $-43 \%$ & $20 \%$ \\
\hline $\mathrm{Zn}$ & $-11 \%$ & $14 \%$ & $21 \%$ \\
\hline \multicolumn{4}{|l|}{ Group III } \\
\hline $\mathrm{Al}$ & $9 \%$ & $19 \%$ & $-4 \%$ \\
\hline $\mathrm{NO}_{3}^{-}$ & $34 \%$ & $25 \%$ & $-10 \%$ \\
\hline $\mathrm{V}^{3}$ & $24 \%$ & $27 \%$ & $-1 \%$ \\
\hline $\mathrm{Ni}$ & $31 \%$ & $36 \%$ & $-6 \%$ \\
\hline
\end{tabular}

Atmos. Chem. Phys., 11, 2917-2931, 2011

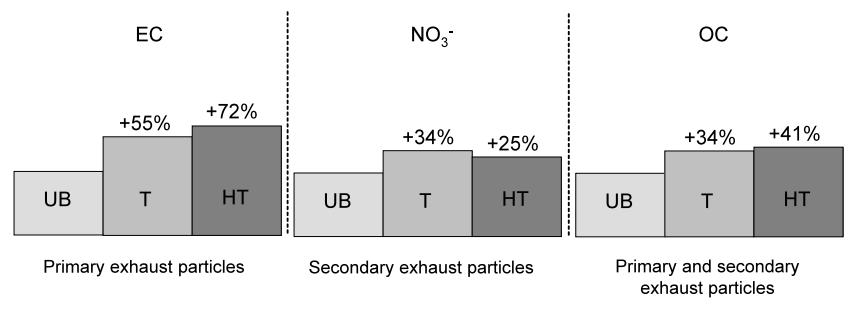

Fig. 3. Roadside enrichment with increasing road traffic emissions for primary and secondary exhaust particles.

$(\mathrm{RE}=35-80 \%)$, and the highest enrichments with traffic volume (HT vs. UB) were obtained for $\mathrm{Sb}(80 \%), \mathrm{Cu}(76 \%)$, Sn (75\%), $\mathrm{Cr}(75 \%), \mathrm{Fe}(73 \%), \mathrm{EC}(72 \%)$ and $\mathrm{Bi}(69 \%)$. With the exception of $\mathrm{Bi}$, all the components with high enrichments (RE $>70 \%)$ are well-known tracers of traffic emissions. Interestingly those pollutants originated by the same traffic sub-source (i.e. brake wear, mineral dust resuspension or primary exhaust) revealed similar REs values. Brake wear elements such as $\mathrm{Fe}, \mathrm{Cu}, \mathrm{Sb}, \mathrm{Cr}$ and $\mathrm{Sn}$ showed REs $\sim 60 \%$ at the $\mathrm{T}$ site and $\sim 75 \%$ at the HT site. Mineral elements such as $\mathrm{Ca}, \mathrm{Ga}, \mathrm{Ti}$ and $\mathrm{Sr}$ were less enriched, around $15 \%$ and $32 \%$ at the T and HT site, respectively. A considerable difference was noted between EC and OC. EC consists exclusively of primary particles and it is enriched by $55 \%$ and $72 \%$, whilst for OC a significant fraction is secondary, thus it is less enriched: $34 \%$ and $41 \%$ respectively at the $\mathrm{T}$ and HT sites (Fig. 3). This would indicate that traffic emissions generate a given background level which affects both traffic sites (HT and T) in a similar way, but which is higher than the urban background levels (at the UB site). The OC/EC ratio increased significantly from the HT, T to the UB sites, confirming that an important fraction of OC is secondary. By applying the EC tracer method (Turpin and Huntzicker, 1995) to estimate the primary and secondary fractions of $\mathrm{OC}$, with a minimum OC/EC ratio of 0.54 representing primary exhaust emissions at the HT site, the following contributions of secondary OC (SOC) to total OC were obtained: $46 \%$ at the HT site, $63 \%$ at the T site, and $78 \%$ at the UB.

Significant, although not major, REs were obtained for As, $\mathrm{Ca}, \mathrm{Cd}, \mathrm{Ga}, \mathrm{La}, \mathrm{PM}_{10}, \mathrm{Sr}$ and $\mathrm{Zr}(\mathrm{RE}=10-34 \%)$. Cd was significantly enriched at $\mathrm{T}$ and $\mathrm{HT}$ with respect to UB (32 and $38 \%$, respectively, Table 2 ), but not between both traffic sites $(1 \%)$. Once more, this would suggest the presence of additional sources of $\mathrm{Cd}$, most probably of industrial origin (Amato et al., 2009a). Most of the variables with minor enrichments include tracers of mineral matter $(\mathrm{Ca}, \mathrm{Ga}, \mathrm{La}, \mathrm{Sr})$, which are emitted through resuspension of road and city dust. Finally, the case of As is noteworthy given that it presents consistent enrichment at the sites with higher traffic volume ( $\mathrm{RE}=12 \%$ and $23 \%$ ) with respect to the urban background, and between both traffic sites ( $\mathrm{RE}=10 \%$ ), thus suggesting a link to traffic emissions. 
Table 2 also shows REs calculated for Group II variables. The low or negative roadside enrichments obtained confirm the sources of the components described above. In addition, the data evidence a lack of trend in the comparison between sites, as opposed to Group I variables which showed consistent REs for all comparisons. Thus, certain elements show always negative REs (e.g., $\mathrm{Na}$ or $\mathrm{Mg}$ ) whereas others show positive and negative REs (e.g., $\mathrm{Pb}, \mathrm{Zn}$ ). The variables with consistently negative REs for all three comparisons $\left(\mathrm{Mg}, \mathrm{SO}_{4}^{2-}, \mathrm{Na}\right)$ coincide with those having a regionalor meso-scale origin.

Finally, the behaviour of Group III variables was also analysed. Nitrate, which was expected to show no enrichment at the traffic sites (similar to $\mathrm{SO}_{4}^{2-}$ and indicating a regionalscale origin), was instead markedly enriched at $\mathrm{T}$ and HT with respect to the UB site (34 and 25\%, respectively, Fig. 3), and lower differences were obtained between both traffic sites (in fact a slight increase at $\mathrm{T}$ with respect to HT, with $\mathrm{RE}=-10 \%$ ). Nitrate levels are indeed of secondary origin at all study locations, but in the traffic areas T and HT the background $\mathrm{NO}_{3}^{-}$levels are higher due to the higher $\mathrm{NO}_{\mathrm{x}}$ emissions. This results in an enrichment in the traffic area with respect to the urban background, which is not evident within the traffic area itself. Thus, our results suggest that $\mathrm{NO}_{3}^{-}$formation occurs within the city on a scale of a few $\mathrm{km}$, but does not need long atmospheric residence times. Similar findings were found by recent studies in UK (Abdalmogith and Harrison, 2006; Dall'Osto et al., 2009). In this sense the $\mathrm{NH}_{3}$ levels are critical: probably the emission of $\mathrm{NH}_{3}$ from diesel vehicles is responsible for high levels of $\mathrm{NH}_{3}$, favouring the rapid formation of $\mathrm{NH}_{4} \mathrm{NO}_{3}$ particles around traffic sites. As for $\mathrm{V}$ and $\mathrm{Ni}$, the REs obtained are of a similar order of magnitude $(24-31 \%$ at $\mathrm{T}$ vs. UB; $27-36 \%$ at HT vs. UB; $(-1)-(-6) \%$ at HT vs. T) due to the fact that they are generally linked in the atmosphere, either originating from fuel-oil or petroleum coke combustion emissions (Pacyna, 1986), and can have a local, regional or long-range exotic origin. In this study area, the fact that these elements were enriched at the traffic sites with respect to the urban background, and not between both traffic sites (REs $<0$ ), could be due to: (a) the closer proximity of the traffic sites to industries located along the coast and to the northwest of the city (Fig. 1) and/or the harbour, or (b) to analytical uncertainty, given that the levels of $\mathrm{V}$ and $\mathrm{Ni}$ are relatively similar at all three sites (Table 1). Finally, the absence of a clear enrichment in the levels of $\mathrm{Al}$ with traffic volume could be due to the influence of other sources such as city dust derived from construction/demolition works.

The daily data obtained at the three study locations were correlated in pairs as a function of traffic intensity: HT vs. UB, and T vs. UB. When analysing the behaviour of the different variables at both pairs of study locations (HT vs. UB, and T vs. UB), positive correlations were observed for most of the major and trace elements (Fig. 2a and $b$ ). This reveals that levels of PM and also of specific
PM-components are mostly regulated by meteorological processes, given that parallel PM trends are detected at traffic and urban background sites in spite of the differences in traffic volume and emissions. Results from the correlation analysis are shown in Fig. 2a and b (based on the L1 norm approximation, Barrodale and Roberts, 1977) and confirmed the classification obtained on the basis of the REs:

- Variables in Group I show a regression line above the 1:1 line (thus enriched with traffic), with good correlation for daily values between sites (Fig. 2a).

- Variables in Group II show a regression line crossing or below the 1:1 line (thus not enriched by traffic), with high or low correlations for daily values between sites (Fig. 2b and Table 2).

- Once more, four variables were considered as exceptions and classified as Group III ( $\mathrm{Al}, \mathrm{NO}_{3}^{-}, \mathrm{V}$ and $\left.\mathrm{Ni}\right)$.

Well-known tracers of primary traffic emissions, such as $\mathrm{EC}, \mathrm{Fe}, \mathrm{Ba}, \mathrm{Cu}$, or $\mathrm{Sb}$ showed enrichments at the sites with higher traffic volume, and so belong in Group I (Fig. 2a and Table 2). Mineral matter (Ca, Ce, Ga, La and Ti) also followed the same trend, as a result of road dust resuspension, and so did OC as a result of OC traffic-derived emissions. However, other tracers linked usually to traffic emissions such as Zn (Sternbeck et al., 2002) or Pb (Adachi and Tainosho, 2004) did not show such a clear enrichment, thus suggesting the influence of other sources, probably metallurgic emissions. $\mathrm{Cd}$ did show enrichment at traffic sites with respect to the urban background, although with a high dispersion of the data points. In addition, other trace elements (As, Bi, Co) were consistently enriched at the sites with higher traffic volume, indicating a link to traffic emissions even though the exact emission process is at this point unclear. Finally, Mo showed a marked enrichment between the HT and UB sites, but not between the T and UB sites, and it was thus not included in Group I (see below). This was interpreted as a result of the analytical uncertainty for this element. Previous studies (Amato et al., 2010) have shown that Mo levels in urban atmospheres may originate from $\mathrm{MoS}_{2}$ used as lubricant in brake pads.

Group II elements included both secondary aerosols (derived or not from traffic emissions) and primary markers of other emission sources (Fig. 2b): $\mathrm{SO}_{4}^{2-}, \mathrm{NH}_{4}^{+}, \mathrm{Na}, \mathrm{Cl}^{-}, \mathrm{Mg}$, $\mathrm{P}, \mathrm{K}, \mathrm{Zn}, \mathrm{Pb}, \mathrm{Rb}, \mathrm{Se}, \mathrm{U}$ and $\mathrm{Li}$. These components were not enriched at the most trafficked sites, and they showed either similar mean levels at all three sites (e.g., $\mathrm{SO}_{4}^{2-}, \mathrm{NH}_{4}^{+}, \mathrm{Na}$, due to their regional-scale origin) or different levels (e.g., $\mathrm{Zn}$, $\mathrm{P}$, due to different emission sources). Mineral elements in this group ( $\mathrm{Li}, \mathrm{P}, \mathrm{Rb}$ ) may be derived from city dust including construction/demolition works, and are thus not linked to traffic emissions. The variables with lowest dispersion in the scatter plots (Fig. 2b) are those linked to regional- or meso-scale origin $\left(\mathrm{SO}_{4}^{2-}, \mathrm{Na}, \mathrm{NH}_{4}^{+}, \mathrm{Mg}\right.$ ), and thus with similar concentrations at all sites. Conversely, the variables with 
different emission sources show different levels at the three sites, and thus a higher dispersion (Fig. 2b).

Four exceptions placed into Group III were detected to these groupings: ( $\mathrm{Al}, \mathrm{NO}_{3}^{-}, \mathrm{V}$ and $\mathrm{Ni}$ ). Aluminum showed only slight enrichments between the UB and the two traffic sites, but no increase from the $\mathrm{T}$ to the HT site. $\mathrm{NO}_{3}^{-}, \mathrm{V}$ and $\mathrm{Ni}$ were expected to be evenly distributed, whilst all three variables showed regression lines clearly above the 1:1 line.

The above-mentioned regression lines (Fig. 2a and b) were calculated by minimizing the absolute value of $(Y-y)$ instead of $(Y-y)^{2}$ (standard least squares method) in order to reduce the influence of outliers. However since the variable in X-axis (UB site) has the same sources and type of uncertainty of variable in y-axis (HT or T site) we also applied the RMA regression (Ayers, 2001) which minimizes the product $(Y-y) \cdot(X-x)$ and present the RMA regression coefficients in Table 3. Differently from that observed by Harrison et al. (2004), in street canyons traffic related pollutants show a slope $>2$ and also a significant intercept with respect to the urban background site (Table 3). This is true for primary particles such as $\mathrm{EC}, \mathrm{Fe}, \mathrm{Cu}, \mathrm{Sb}$ and $\mathrm{Cr}$ which are almost exclusively emitted by road traffic. $\mathrm{PM}_{10}$ and crustal materials, originated by road dust emissions but also by other nontraffic sources, showed a similar but smoother pattern (lower slope and intercept). The significant differences between HT and $\mathrm{T}$ street canyons, observed for $\mathrm{Cu}$ and $\mathrm{Cr}$, remain unclear.

\subsection{Road traffic signatures}

The analysis of the concentration increments of specific elements and components at the HT site with respect to the $\mathrm{T}$ site, and at $\mathrm{T}$ with respect to $\mathrm{UB}$, allows for the determination of ratios which may be characteristic of road traffic emissions. These ratios may be considered signatures of road traffic emissions, and be used in, i.e., source apportionment studies.

Based on the EC and OC increments at HT with respect to $\mathrm{T}$, and $\mathrm{T}$ with respect to $\mathrm{UB}, \mathrm{OC} / \mathrm{EC}$ ratios were calculated (Table 4). These ratios were determined as follows: the difference between $\mathrm{HT}_{\mathrm{OC}}$ and $\mathrm{T}_{\mathrm{OC}}$ was calculated, and the same was done for $\mathrm{HT}_{\mathrm{EC}}$ and $\mathrm{T}_{\mathrm{EC}}$, and then the ratio between the two values (OC/EC ratio of the roadside increment) was obtained. The same was done for T and UB to obtain the urban increment. In this way, the $\mathrm{OC} / \mathrm{EC}$ ratio of the roadside increment (HT vs. T) was 0.28 , whereas the ratio of the urban increment ( $\mathrm{T}$ vs. UB) was 0.52 , mainly resulting from the larger $\mathrm{EC}$ than $\mathrm{OC}$ increment registered at HT. These ratios are of the same order of magnitude as the roadside and urban increments for OC/EC registered in Birmingham (0.38 and 0.29, respectively, Harrison and Yin, 2008), even if the urban increment was relatively higher in our study. In addition, EC/TC ratios were also analysed and compared with that characteristic of emissions from heavy duty diesel vehicles $(\mathrm{EC} / \mathrm{TC}=0.78$; USEPA, 2002). EC/TC ratios in our study were 0.78 and 0.66 for the roadside and urban increments, respectively, and are thus consistent with those characteristic of diesel road traffic emissions. According to national statistics, $70 \%$ of all new vehicles in 2010 and $40 \%$ of the total vehicle fleet is comprised of diesel vehicles in Barcelona (DGT, 2011).

A similar analysis was carried out for trace element concentrations. Roadside and urban increments were determined for Group I elements with REs $>35 \%$ for all types of sites, as well as for Group II and II elements (variables not enriched at the site with higher traffic volume, only certain ratios calculated for comparison). As shown in Table 4, similar ratios were obtained for roadside and urban increments between Group III elements $(\mathrm{Cu}, \mathrm{Sb}, \mathrm{Sn}, \mathrm{Fe})$, thus confirming the ability of these ratios to represent road traffic emissions. The lowest variability and thus higher stability of the ratios (see standard deviations in Table 4) was obtained for $\mathrm{Cu}$, $\mathrm{Sb}$ and $\mathrm{Sb}(\mathrm{Cu} / \mathrm{Sb}=6.8-8.0 ; \mathrm{Cu} / \mathrm{Sn}=4.7-5.4 ; \mathrm{Sn} / \mathrm{Sb}=1.49-$ $1.50)$, in comparison with $\mathrm{Fe}(\mathrm{Fe} / \mathrm{Sn}=93-109 ; \mathrm{Fe} / \mathrm{Sb}=137-$ $158 ; \mathrm{Fe} / \mathrm{Cu}=17-29)$. Despite this relative variability, enrichment ratios for these elements may be considered comparable in the roadside and urban environments, and thus characteristic of road traffic emissions. Conversely, the ratios for Group II and II variables were markedly different in the roadside and urban environments (ratios calculated for a few number of variables, as an example for comparison).

\subsection{Hourly-based size-segregated speciation data}

The hourly evolution of elemental concentrations was investigated in order to better determine whether increments at traffic sites were effectively due to traffic emissions or to other sources. Two different size fractions were investigated $(<2.5 \mu \mathrm{m}$ and $2.5-10 \mu \mathrm{m})$ at the heavy traffic and urban background sites. Results showed that the hourly evolution of certain pollutants was driven by the same processes at both sites, whereas that of others revealed different patterns in the UB and the HT sites (Figs. 4 and 5).

The main elements which were strongly influenced by road traffic emissions both at the UB and HT sites in the fine and coarse PM fractions, were $\mathrm{Fe}, \mathrm{Cu}, \mathrm{Cr}, \mathrm{Sn}, \mathrm{Mo}, \mathrm{Sb}$ and $\mathrm{Zr}$. This may be seen in the parallel trends observed for these elements and the number of vehicles as a function of wind speed (Figs. 4 and 5). The parameter "vehicles as a function of wind speed" allows us to estimate the traffic volume while compensating for fluctuations in wind speed (Rodríguez et al., 2008), something which is critical at coastal locations under a strong influence of sea breeze circulations such as Barcelona. Therefore, the number of vehicles divided by wind speed provides an accurate estimation of the daily cycle of the vehicle contribution to the concentrations. As shown in Figs. 4 and 5, the daily cycles of fine and coarse levels of $\mathrm{Fe}$ and $\mathrm{Cu}$ follow the number of vehicles as a function of wind speed rather closely, at both study locations. The case of $\mathrm{Cr}$ is interesting, given that in the fine mode in the urban background this element did not seem to coincide with the 
Table 3. RMA regression coefficients calculated for traffic-related pollutants concentrations $\left(\mu \mathrm{g} \mathrm{m}^{-3}\right)$ between heavy traffic vs. background and traffic vs. background stations.

\begin{tabular}{|c|c|c|c|c|c|c|c|c|}
\hline & \multicolumn{4}{|c|}{ HT vs. UB } & \multicolumn{4}{|c|}{ T vs. UB } \\
\hline & Mean at HT & Slope & Intercept & Intercept (\%) & Mean at $\mathrm{T}$ & Slope & Intercept & Intercept $(\%)$ \\
\hline $\mathrm{EC}$ & 5.8 & 2.01 & 2.6 & 45 & 1.6 & 1.75 & 0.9 & 57 \\
\hline $\mathrm{Fe}$ & 2.1 & 2.14 & 0.9 & 44 & 0.6 & 1.96 & 0.3 & 54 \\
\hline $\mathrm{Cu}^{*}$ & 105.7 & 2.41 & 45.5 & 43 & 62.6 & 2.19 & 8.0 & 13 \\
\hline $\mathrm{Sb}^{*}$ & 13.7 & 3.27 & 5.3 & 38 & 2.6 & 3.15 & 0.2 & 7 \\
\hline $\mathrm{Cr}^{*}$ & 17.7 & 2.97 & 5.4 & 31 & 14.8 & 3.71 & -0.8 & \\
\hline $\mathrm{OC}$ & 6.2 & 1.78 & -0.2 & 3.5 & 1.88 & -1.0 & & \\
\hline $\mathrm{NO}_{3}^{-}$ & 5.2 & 1.25 & 0.0 & 1 & 4.1 & 1.52 & -0.2 & \\
\hline $\mathrm{PM}_{10}$ & 54.1 & 1.23 & 7.0 & 13 & 38.3 & 1.192 .3 & 6 & \\
\hline $\mathrm{Ca}$ & 2.4 & 1.23 & 0.7 & 28 & 1.4 & 1.04 & 0.4 & 29 \\
\hline $\mathrm{Al}_{2} \mathrm{O}_{3}$ & 1.1 & 1.11 & 0.2 & 21 & 0.8 & 1.07 & 0.2 & 20 \\
\hline $\mathrm{K}$ & 0.4 & 1.13 & 0.0 & 9 & 0.3 & 1.10 & 0.0 & 3 \\
\hline $\mathrm{Mn}^{*}$ & 29.6 & 1.50 & 9.8 & 33 & 13.1 & 1.35 & 3.6 & 28 \\
\hline $\mathrm{Ti}^{*}$ & 46.8 & 1.32 & 10.5 & 22 & 27.4 & 1.09 & 8.1 & 30 \\
\hline
\end{tabular}

* Values in $\mathrm{ng} \mathrm{m}^{-3}$.

Table 4. Road traffic trace element signatures based on the ratios between the roadside and urban increments calculated for each element as the difference between the concentrations (in $\mathrm{ng} \mathrm{m}^{-3}$ ) at the HT and T sites, and at the T and UB sites. Ratios calculated on a sample-by-sample basis.

\begin{tabular}{lll}
\hline & $\begin{array}{l}\text { Roadside } \\
\text { (HT vs. T) }\end{array}$ & $\begin{array}{l}\text { Urban } \\
\text { (T vs. UB) }\end{array}$ \\
\hline \multicolumn{3}{c}{ REs $>35 \%$ for HT, T, UB } \\
\hline $\mathrm{OC} / \mathrm{EC}$ & $0.28( \pm 0.8)$ & $0.52( \pm 1.3)$ \\
$\mathrm{Cu} / \mathrm{Sb}$ & $8.0( \pm 1.5)$ & $6.8( \pm 1.9)$ \\
$\mathrm{Cu} / \mathrm{Sn}$ & $5.4( \pm 0.6)$ & $4.7( \pm 1.3)$ \\
$\mathrm{Fe} / \mathrm{Sn}$ & $93( \pm 20)$ & $109( \pm 24)$ \\
$\mathrm{Fe} / \mathrm{Sb}$ & $137( \pm 29)$ & $158( \pm 32)$ \\
$\mathrm{Sn} / \mathrm{Sb}$ & $1.5( \pm 0.3)$ & $1.5( \pm 0.3)$ \\
$\mathrm{Fe} / \mathrm{Cu}$ & $17( \pm 3)$ & $29( \pm 26)$ \\
\hline & $\mathrm{REs}<35 \%(\mathrm{examples})$ \\
\hline $\mathrm{Cu} / \mathrm{Cl}{ }^{-}$ & $0.04( \pm 0.22)$ & $0.12( \pm 0.40)$ \\
$\mathrm{Cu} / \mathrm{Ni}$ & $49( \pm 79)$ & $2( \pm 84)$ \\
$\mathrm{Sb} / \mathrm{Ni}$ & $6( \pm 10)$ & $0.9( \pm 11)$ \\
$\mathrm{Sb} / \mathrm{Na}$ & $0.1( \pm 0.6)$ & $0.05( \pm 0.1)$ \\
$\mathrm{Fe} / \mathrm{Al}$ & $6( \pm 10)$ & $5( \pm 6)$ \\
\hline
\end{tabular}

daily traffic cycle. Conversely, the daily evolution of fine $\mathrm{Cr}$ seemed to be driven by the emissions from a different source, possibly an industrial source (steel manufacture) with maximal levels at 10:00 a.m. (local time).

For the species with a clear traffic origin (Fe, $\mathrm{Cu}, \mathrm{Cr}, \mathrm{Sn}$, $\mathrm{Mo}, \mathrm{Sb}$ and $\mathrm{Zr}$ ), the excess concentrations at the heavy traffic site with respect to the urban background may be attributed entirely to the local emissions. The percentage of this excess to the total mass is somewhat higher in the fine fraction than in the coarse one (Table 5): from 32\% (Zr), 70-80\% (Mo, $\mathrm{Fe}$ and $\mathrm{Cu}$ ), $>80 \%$ ( $\mathrm{Sn}, \mathrm{Cr}$ and $\mathrm{Sb}$ ) in the fine fraction whilst from 4 and $25 \%$ (for $\mathrm{Zr}$ and Mo, respectively), up to 64$79 \%$ (for $\mathrm{Sb}, \mathrm{Sn}, \mathrm{Cr}, \mathrm{Fe}$ and $\mathrm{Cu}$ in increasing order) in the coarse fraction. These hourly excess concentrations coincide mostly with the daily roadside enrichments described in the previous section. On a daily basis, the highest increments at HT occurred at 08:00 and 20:00, due to the combined effect of high traffic intensity and low sea-breeze speed.

Other elements also showed strong enrichments at the HT site, but the entire excess could not be attributed solely to traffic emissions. Crustal elements such as Al and Si (fine), and $\mathrm{Ca}$ and $\mathrm{Sr}$ (fine and coarse) showed in fact different increments due to the local road traffic emissions (08:00 a.m.) and to the urban works yielding total increments of up to $30-40 \%$ at the HT site from 12:00 to 18:00. The UB concentrations revealed the same pattern. As already mentioned, the sea breeze typically develops from the S-SW sectors, where also a number of important urban works were being carried out during our campaign, such as the construction of a new Underground line and a new high velocity railway. As a result, we interpret the midday peak as mineral urban dust transported by the sea breeze towards the study locations. This effect is stronger in the fine fraction. Regarding the first morning peak, a certain correlation was observed at HT between $\mathrm{Ca}$ and traffic tracers between 07:00 and 09:00 a.m., indicating that $\mathrm{Ca}$ is emitted by road traffic by means of resuspension of road dust. In addition, coarse Si and Al levels showed the same traffic peak even though it was not high 


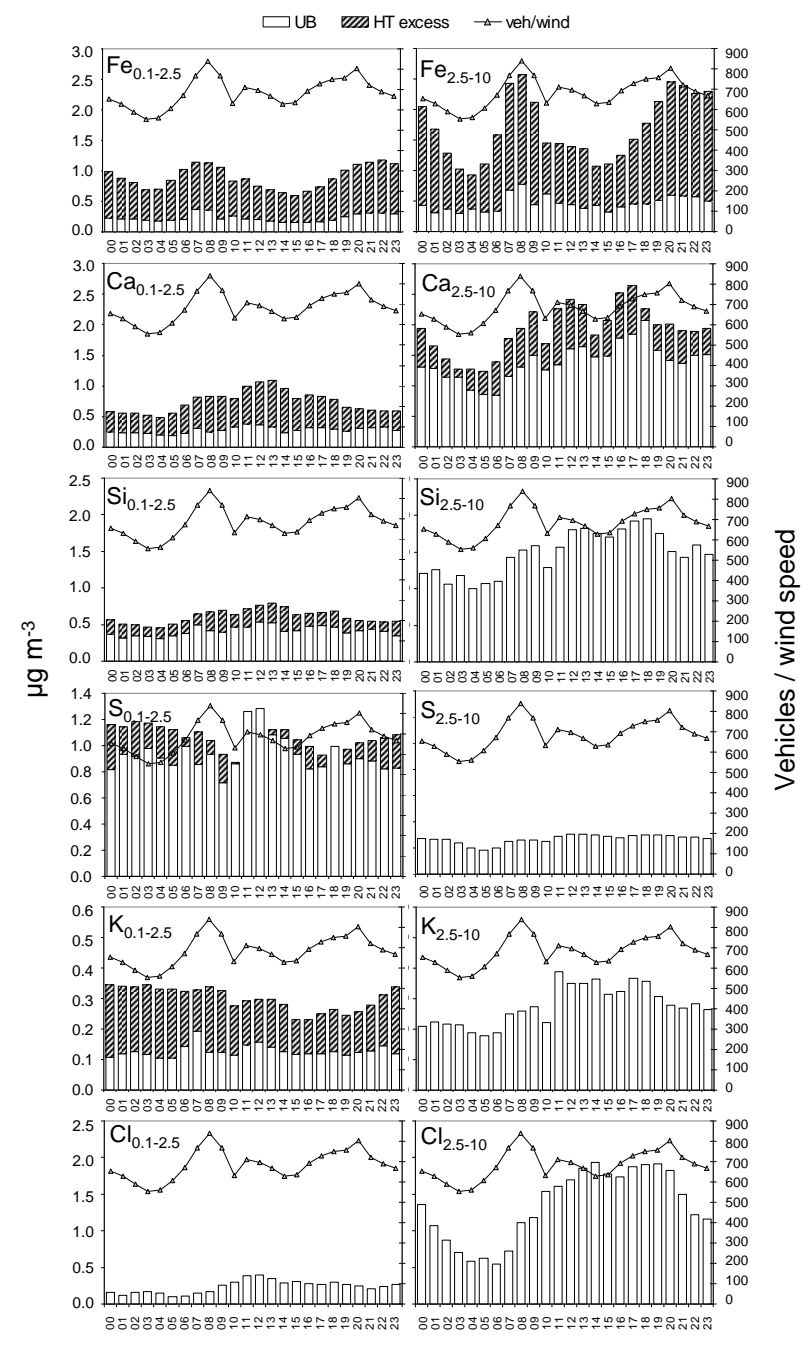

Fig. 4. Hourly variability of major elements concentrations at the UB site and excess registered at the HT site. On the right axis is depicted the number of vehicles normalized by the actual wind speed.

enough to overcome the UB level, and therefore no enrichment may be calculated for the coarse fraction of $\mathrm{Si}$ and $\mathrm{Al}$. This coincides with the results described for $\mathrm{Al}$ in the previous section, where traffic enrichments were observed for $\mathrm{Al}$ but not systematically.

Road traffic emissions at the HT site produced local increases for coarse $\mathrm{Zn}$ and coarse $\mathrm{Mn}$, whereas the fine fractions of these elements showed a very different pattern. In $\mathrm{PM}_{2.5}$ no excess of $\mathrm{Zn}$ was observed at the HT site and the daily distribution indicates a clear transport during night from the northwestern industrial cluster. This industrial source was previously identified by Amato et al. (2009a) and related to emissions from smelters, associated also with $\mathrm{Pb}$. On average, $15 \%$ and $53 \%$ of coarse $\mathrm{Zn}$ and Mn at HT site were due to the local road traffic emissions. In the case of $\mathrm{Zn}$, the existence of at least two emission sources confirms the results presented in Table 2, where $\mathrm{Zn}$ was classified as

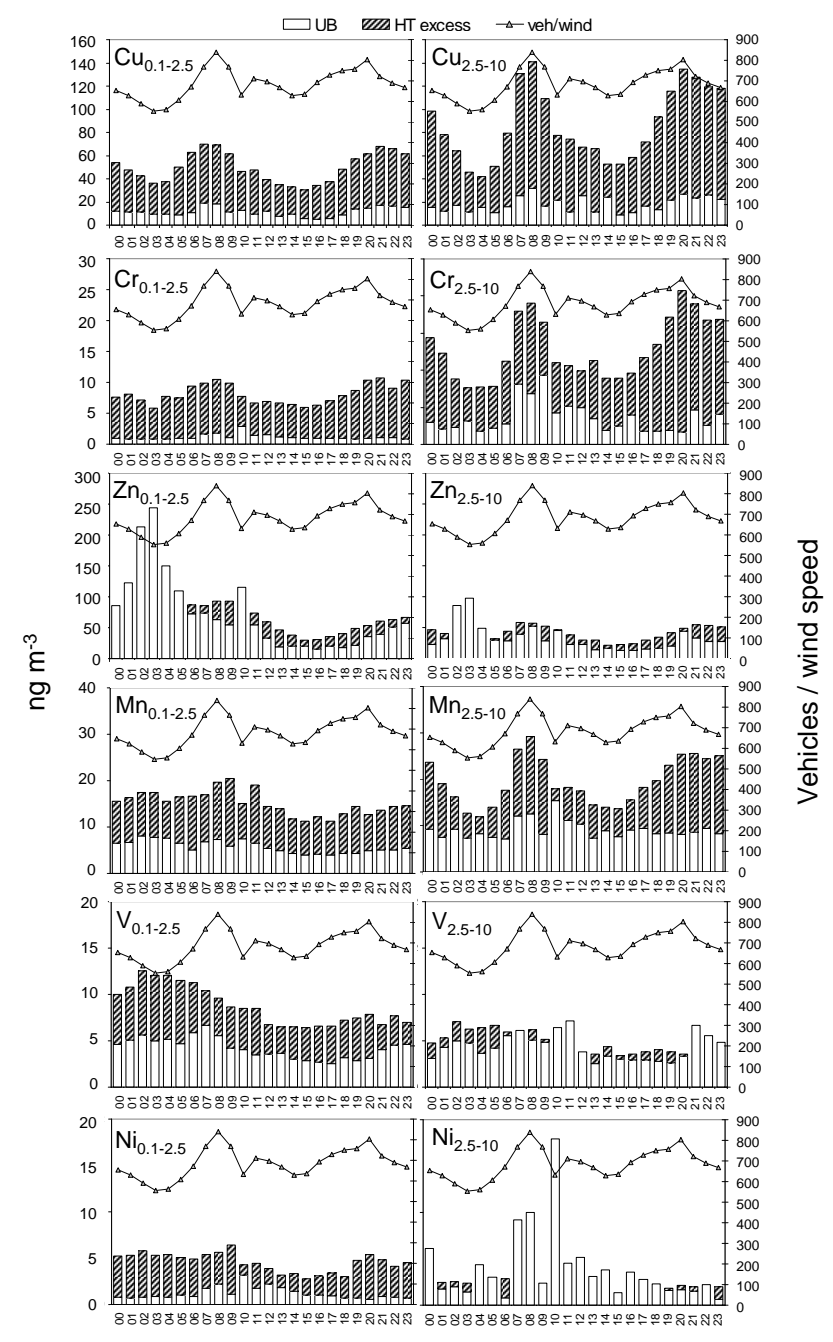

Fig. 5. Hourly variability of trace elements concentrations at the UB site and excess registered at the HT site. On the right axis is depicted the number of vehicles normalized by the actual wind speed.

a Group II variable, with an enrichment between the traffic sites but not consistently between the urban background, the traffic and the heavy traffic sites. Similarly to Mn, clear traffic enrichments were detected by means of the analysis of the daily data (Group I variable, Table 2), probably due to the coarse grain size distribution of this element (ratio fine $/$ coarse $=0.63$ ).

In the urban background, and similarly to fine $\mathrm{Cr}$, the hourly variability of coarse $\mathrm{Mn}$ was driven by a possible local steel source, rather than by road traffic emissions. This is also supported by the same pattern observed for $\mathrm{Ni}$ (fine and coarse). Actually, Ni turned out to be a complex multiplesource pollutant. At the UB site a major peak was registered at midday in combination with $\mathrm{Cr}$ (fine) and $\mathrm{Mn}$ (coarse), revealing a stainless steel source not found at the HT site, where concentrations were smaller and driven by local traffic. Similarly to crustal species, road traffic is not the only 
Table 5. Percentage of elemental concentrations registered at the HT site due to local sources. Mean values from 10 March to 27 March.

\begin{tabular}{|c|c|c|c|c|}
\hline 7 & & $\begin{array}{c}\text { Impact of local } \\
\text { sources (\% of mass) }\end{array}$ & Source of excess mass & Source at UB \\
\hline $\mathrm{Al}$ & $\begin{array}{l}\text { fine } \\
\text { coarse }\end{array}$ & 38 & Traffic + Construction & $\begin{array}{l}\text { Construction } \\
\text { Construction }\end{array}$ \\
\hline $\mathrm{Ca}$ & $\begin{array}{l}\text { fine } \\
\text { coarse }\end{array}$ & $\begin{array}{l}62 \\
27\end{array}$ & $\begin{array}{l}\text { Traffic }+ \text { Construction } \\
\text { Traffic }+ \text { Construction }\end{array}$ & $\begin{array}{l}\text { Traffic }+ \text { Construction } \\
\text { Traffic }+ \text { Construction }\end{array}$ \\
\hline $\mathrm{Cl}$ & $\begin{array}{l}\text { fine } \\
\text { coarse }\end{array}$ & & & $\begin{array}{l}\text { Sea salt } \\
\text { Sea salt }\end{array}$ \\
\hline $\mathrm{Cr}$ & $\begin{array}{l}\text { fine } \\
\text { coarse }\end{array}$ & $\begin{array}{l}86 \\
72\end{array}$ & $\begin{array}{l}\text { Traffic } \\
\text { Traffic }\end{array}$ & $\begin{array}{l}\text { Steel production } \\
\text { Traffic }\end{array}$ \\
\hline $\mathrm{Cu}$ & $\begin{array}{l}\text { fine } \\
\text { coarse }\end{array}$ & $\begin{array}{l}77 \\
79\end{array}$ & $\begin{array}{l}\text { Traffic } \\
\text { Traffic }\end{array}$ & $\begin{array}{l}\text { Traffic } \\
\text { Traffic }\end{array}$ \\
\hline $\mathrm{Fe}$ & $\begin{array}{l}\text { fine } \\
\text { coarse }\end{array}$ & $\begin{array}{l}75 \\
73\end{array}$ & $\begin{array}{l}\text { Traffic } \\
\text { Traffic }\end{array}$ & $\begin{array}{l}\text { Traffic } \\
\text { Traffic }\end{array}$ \\
\hline $\mathrm{K}$ & $\begin{array}{l}\text { fine } \\
\text { coarse }\end{array}$ & 58 & Cooking/Smoking & Sea salt + mineral \\
\hline $\mathrm{Mn}$ & $\begin{array}{l}\text { fine } \\
\text { coarse }\end{array}$ & $\begin{array}{l}62 \\
53\end{array}$ & $\begin{array}{l}\text { Industrial } \\
\text { Traffic }\end{array}$ & $\begin{array}{l}\text { Industrial } \\
\text { Metallurgy }\end{array}$ \\
\hline Mo & $\begin{array}{l}\text { fine } \\
\text { coarse }\end{array}$ & $\begin{array}{l}69 \\
25\end{array}$ & $\begin{array}{l}\text { Traffic } \\
\text { Traffic }\end{array}$ & $\begin{array}{l}\text { Traffic } \\
\text { Traffic }\end{array}$ \\
\hline $\mathrm{Ni}$ & $\begin{array}{l}\text { fine } \\
\text { coarse }\end{array}$ & 74 & Fuel oil + Traffic & $\begin{array}{l}\text { Steel production } \\
\text { Steel production }\end{array}$ \\
\hline $\mathrm{P}$ & $\begin{array}{l}\text { fine } \\
\text { coarse }\end{array}$ & $\begin{array}{l}42 \\
14\end{array}$ & & $\begin{array}{l}\text { No pattern } \\
\text { No pattern }\end{array}$ \\
\hline $\mathrm{Rb}$ & $\begin{array}{l}\text { fine } \\
\text { coarse }\end{array}$ & 58 & & $\begin{array}{l}\text { No pattern } \\
\text { No pattern }\end{array}$ \\
\hline S & $\begin{array}{l}\text { fine } \\
\text { coarse }\end{array}$ & $13^{*}$ & Fuel oil from inland & $\begin{array}{l}\text { Regional } \\
\text { Sea salt }\end{array}$ \\
\hline $\mathrm{Sb}$ & $\begin{array}{l}\text { fine } \\
\text { coarse }\end{array}$ & $\begin{array}{l}90 \\
64\end{array}$ & $\begin{array}{l}\text { Traffic } \\
\text { Traffic }\end{array}$ & $\begin{array}{l}\text { Traffic } \\
\text { Traffic }\end{array}$ \\
\hline $\mathrm{Si}$ & $\begin{array}{l}\text { fine } \\
\text { coarse }\end{array}$ & 32 & Traffic + Construction & $\begin{array}{l}\text { Construction } \\
\text { Construction }\end{array}$ \\
\hline $\mathrm{Sn}$ & $\begin{array}{l}\text { fine } \\
\text { coarse } \\
\text { fine } \\
\text { coarse }\end{array}$ & $\begin{array}{l}83 \\
67 \\
51 \\
16\end{array}$ & $\begin{array}{l}\text { Traffic } \\
\text { Traffic } \\
\text { Traffic + Construction } \\
\text { Traffic + Construction }\end{array}$ & $\begin{array}{l}\text { Traffic } \\
\text { Traffic } \\
\text { Traffic + Construction } \\
\text { Traffic + Construction }\end{array}$ \\
\hline $\mathrm{Ti}$ & $\begin{array}{l}\text { fine } \\
\text { coarse }\end{array}$ & $\begin{array}{l}69 \\
30\end{array}$ & $\begin{array}{l}\text { Traffic }+ \text { Construction } \\
\text { Traffic }+ \text { Construction }\end{array}$ & $\begin{array}{l}\text { Traffic }+ \text { Construction } \\
\text { Traffic }+ \text { Construction }\end{array}$ \\
\hline $\mathrm{V}$ & $\begin{array}{l}\text { fine } \\
\text { coarse }\end{array}$ & $\begin{array}{c}55 \\
6\end{array}$ & $\begin{array}{l}\text { Fuel oil from inland } \\
\text { Fuel oil from inland }\end{array}$ & $\begin{array}{l}\text { Fuel oil from inland } \\
\text { Fuel oil from inland }+ \text { shipping }\end{array}$ \\
\hline $\mathrm{Zn}$ & $\begin{array}{l}\text { fine } \\
\text { coarse }\end{array}$ & 15 & Traffic & $\begin{array}{l}\text { Metallurgy } \\
\text { Traffic + Industrial }\end{array}$ \\
\hline $\mathrm{Zr}$ & $\begin{array}{l}\text { fine } \\
\text { coarse }\end{array}$ & $\begin{array}{c}32 \\
4\end{array}$ & $\begin{array}{l}\text { Traffic } \\
\text { Traffic }\end{array}$ & $\begin{array}{l}\text { Traffic }+ \text { Construction } \\
\text { Traffic }+ \text { Construction }\end{array}$ \\
\hline
\end{tabular}

\footnotetext{
* The value for $\mathrm{S}$ does not coincide to Table 2 due to the different dates use for mean values.
} 
source responsible of the excess registered at the HT site in the fine fraction of $\mathrm{Ni}(+74 \%)$. Higher concentrations with respect to the UB site were registered during the whole day with maxima coinciding with rush hour traffic and at night. We interpret this as the impact of the fuel oil combustion products transported from inland towards the coast.

The night excess (Figs. 4 and 5) of pollutant concentrations at HT is not characteristic only of fine $\mathrm{Ni}$, but also of $\mathrm{V}$ (fine and coarse), suggesting the presence of plumes from northwesterly fuel oil combustion sources. The excess can be estimated in $55-74 \%$ and could also be related to the excess registered for fine $\mathrm{K}(58 \%)$ at HT. A certain correlation was also found in the afternoon hours between the excess of fine $\mathrm{K}$ and $\mathrm{S}$. These correlations, beside analytical uncertainty, could point towards some local impact from cooking/smoking activities in the vicinity of the monitoring site (located in a highly populated commercial area), or even to pollutant transport from inland by land breezes.

Finally, other elements showed no enrichment at the HT site. These are typical coarse sea salt ions such as K, S, and $\mathrm{Cl}^{-}$(also fine) and coarse crustal material such as $\mathrm{Si}$ and $\mathrm{Al}$, more likely related to urban construction/demolition works, rather than vehicle-induced resuspension.

The roadside increments showed in Figs. 4 and 5 may be overestimated due to the street canyon recirculation. We evaluated the relationship between pollutant increments and wind speed from distinct sectors following the same approach of Harrison et al. (2004). For hourly increments we observed a decreasing trend with an increase of hourly averaged wind speed from the sector $45-225^{\circ}$. This sector corresponds to the sea-breeze activation (10:00 a.m.-10:00 p.m.) and as expected by literature studies (Berkowicz, 2000; Harrison et al., 2004) it provoked a recirculation plume inside the street with pollutant accumulation at the leeward side of the street. Therefore, being the mobile laboratory station located at the windward side, lower concentrations of traffic markers such as $\mathrm{Cu}$ and $\mathrm{Fe}$ were registered as wind speed from the $45-225^{\circ}$ was increasing (Fig. 6). This yields to a slight overestimation of kerbside increments of pollutants presented. However when plotting the increments against wind speed from the opposite sector, no increasing trend was observed, revealing that probably street canyon effects in the study area exist but are not so strong like in previous studies in London for example (Harrison et al., 2004).

\section{Conclusions}

Size and time-resolved roadside enrichments of atmospheric particulate pollutants were detected and quantified in a Mediterranean urban environment (Barcelona, Spain). Simultaneous data from three urban locations were analysed: one urban background (UB), one traffic (T) and one heavy traffic (HT) site. Hourly-resolved PM speciation data proved

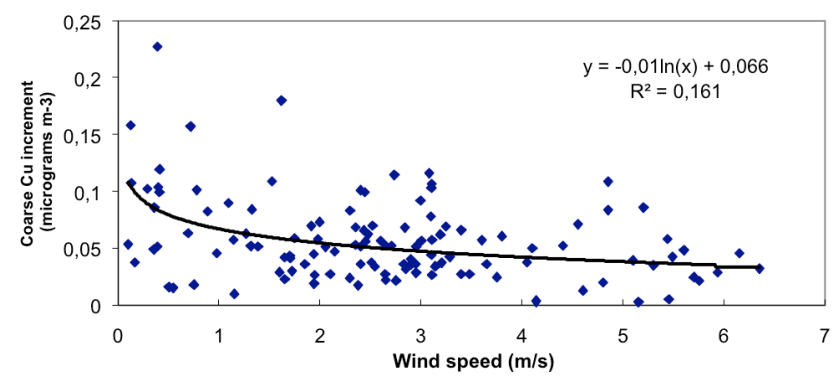

Fig. 6. Increment of coarse $\mathrm{Cu}$ during hours with wind direction $45-225^{\circ}$ (sea-breeze scenario).

to be a highly resourceful tool to determine the source origin of atmospheric pollutants in urban environments.

Elements and PM components with significant roadside enrichments were:

- Tracers of primary traffic emissions: $\mathrm{EC}, \mathrm{Fe}, \mathrm{Ba}, \mathrm{Cu}$, $\mathrm{Sb}, \mathrm{Cr}$ and $\mathrm{Sn}$, with roadside enrichments (RE) $>70 \%$ (between the heavy traffic site and the urban background). Other traffic tracers such as $\mathrm{Cd}$ and $\mathrm{Zr}$ showed lower but still consistent roadside enrichments $(38 \%$ and $26 \%$, respectively).

- Mineral matter resulting from road dust resuspension: $\mathrm{Ca}, \mathrm{La}, \mathrm{Ce}, \mathrm{Ti}, \mathrm{Ga}$ and $\mathrm{Sr}$ with roadside enrichments $=30-40 \%$.

- Organic carbon resulting from primary and secondary traffic-derived emissions: $41 \%$. Contributions of secondary OC (SOC) to total OC were: $46 \%$ at the HT site, $63 \%$ at the $\mathrm{T}$ site, and $78 \%$ at the UB.

- Additional trace elements: As, Co and Bi, with roadside enrichments of $23 \%, 47 \%$ and $69 \%$, respectively. These REs indicate a link to traffic emissions, even though the emission process is unclear.

The roadside enrichment of $\mathrm{Mn}$ revealed by the daily data was elucidated by the analysis of the size- and hourlyresolved daily time series. This analysis showed that $62 \%$ of fine Mn at the HT site was attributable to industrial plumes from the inland regions. In the coarse fraction, 53\% of Mn originated from road traffic emissions. Similarly, $15 \%$ of coarse $\mathrm{Zn}$ was attributed to road traffic emissions.

No consistent enrichments were obtained for markers of secondary aerosols and for primary markers of other emission sources: $\mathrm{SO}_{4}^{2-}, \mathrm{NH}_{4}^{+}, \mathrm{Na}, \mathrm{Cl}^{-}, \mathrm{Mg}, \mathrm{P}, \mathrm{K}, \mathrm{Zn}, \mathrm{Pb}, \mathrm{Rb}$, $\mathrm{Se}, \mathrm{U}, \mathrm{Li}$. Mineral elements in this group ( $\mathrm{Li}, \mathrm{Rb}, \mathrm{Sr}$ ) may be derived from city dust including construction/demolition works. The variables with highest correlation values when comparing the HT and T sites with respect to the urban background were those linked to regional- or meso-scale origin $\left(\mathrm{SO}_{4}^{2-}, \mathrm{NH}_{4}^{+}, \mathrm{Na}, \mathrm{Mg}\right)$. 
Four exceptions were detected: $\mathrm{Al}, \mathrm{NO}_{3}^{-}, \mathrm{V}$ and $\mathrm{Ni}$. These variables showed roadside enrichments with respect to the urban background, but not between both traffic sites. Levels of $\mathrm{Al}$ (and $\mathrm{Si}$ ) were slightly higher at traffic sites than in the urban background (10-20\%). Nevertheless, the increase of these components due to traffic emissions was observed only in the fine fraction (maximum of $38 \%$ of the fine fraction). The coarse fraction was clearly influenced by city dust and construction works, with highest contributions in the afternoon hours.

Nitrate was markedly enriched at $\mathrm{T}$ and HT with respect to the UB site (25-35\%). This suggests that $\mathrm{NO}_{3}^{-}$formation occurs on the city-scale within a few $\mathrm{km}$, and it does not require long atmospheric residence times. Finally, despite their industrial origin, $\mathrm{V}$ and $\mathrm{Ni}$ showed roadside enrichments. These enrichments could be due to the closer proximity of the traffic sites to the industries and harbour.

Characteristic road traffic ratios were 0.28 for the roadside OC/EC increment (HT vs. T) and 0.52 for the urban increment ( $\mathrm{T}$ vs. UB). Similar ratios were calculated between road traffic markers $(\mathrm{Cu}, \mathrm{Sb}, \mathrm{Sn})$, with the following ratios being identified as tracers of road traffic emissions: $\mathrm{Cu} / \mathrm{Sb}=7.0$ 7.9; $\mathrm{Cu} / \mathrm{Sn}=4.7-4.8 ; \mathrm{Sn} / \mathrm{Sb}=1.5-1.6$.

Our results shed light on the relationship between ambient air concentrations of particulate pollutants (and consequently population exposure) and horizontal distance to road traffic emissions. This study shows that, despite the increase of the regulated $\mathrm{PM}_{10}$ mass resulted to be around $25 \%$, the ambient concentrations of metals increased by $70 \%$ (or higher) at heavily trafficked areas with respect to the urban background. Since the epidemiological studies are currently dealing only with $\mathrm{PM}_{10}$ and $\mathrm{PM}_{2.5}$ mass concentrations, our results suggest that other (more source-specific) parameters should be taken into account.

Acknowledgements. This work was funded by the Spanish Ministry of the Science and Innovation (CGL2007-30502-E/CLI, VAMOS CGL2010-19464-CLI), the Ministry of the Environment and Rural and Marine Affairs (010/PC08/3-04.1), the I3P (JAE-CSIC) and Ramón y Cajal Programmes and research projects DOASURCGL2007-62505/CLI and GRACCIE- CSD2007-00067. Portions of this research were carried out at the Swiss Light Source, beamline X05DA, Paul Scherrer Institut, Villigen, Switzerland and at the light source facility DORIS III at HASYLAB/DESY. DESY is a member of the Helmholtz Association (HGF).

Edited by: E. Vignati

\section{References}

Abdalmogith, S. S. and Harrison, R. M.: An Analysis of Spatial and Temporal Properties of Daily Sulphate, Nitrate and Chloride Concentrations at UK Urban and Rural Sites, J. Environ. Monit., 8, 691-699, 2006.

Adachi, K. and Tainosho, Y.: Characterization of heavy metal particles embedded in tire dust, Environ. Int., 30, 1009-1-017, 2004.
Almeida, S. M., Pio, C. A., Freitas, M. C., Reis, M. A., Trancoso, M. A.: Source apportionment of fine and coarse particulate matter in a sub-urban area at the Western European Coast, Atmos. Environ., 39, 3127-3138, 2005.

Amato F., Pandolfi, M., Escrig, A., Querol, X., Alastuey, A., Pey, J., Perez, N., and Hopke, P. K.: Quantifying road dust resuspension in urban environment by Multilinear Engine: a comparison with PMF2, Atmos. Environ., 43(17), 2770-2780, 2009a.

Amato, F., Pandolfi, M., Viana, M., Querol, X., Alastuey, A., and Moreno, T.: Spatial and chemical patterns of $\mathrm{PM}_{10}$ in road dust deposited in urban environment, Atmos. Environ., 43(9), 16501659, 2009b.

Amato F., Querol X., Alastuey A., Pandolfi M., Moreno T., Gracia J., and Rodriguez P.: Evaluating urban $\mathrm{PM}_{10}$ pollution benefit induced by street cleaning activities, Atmos. Environ., 43(29), 4472-4480, 2009c.

Amato F., Nava S., Lucarelli F., Querol X., Alastuey A., Baldasano J. M., and Pandolfi, M. A: Comprehensive assessment of PM emissions from paved roads: Real-world Emission Factors and intense street cleaning trials, Sci. Total Environ., 408(20), 43094318, 2010.

Ayers, G. P.: Comment on regression analysis of air quality data, Atmos. Environ., 35, 2423-2425, 2001.

Barrodale, I. and Roberts, F. D. K.: Algorithms for restricted least absolute value estimation, C. S. Simulat., Commun. Statis.Simula. Computa. B, 6, 353-363, 1977.

Berkowicz, R.: OSPM - A parameterised street pollution model. Environmental Monitoring and Assessment, 65, 323-331, 2000.

Birch, M. E. and Cary, R. A.: Elemental carbon-based method for monitoring occupational exposures to particulate diesel exhaust, Aerosol. Sci. Tech., 25, 221-241, 1996.

Bruinen de Bruin, Y., Koistinen, K., Yli-Tuomi, T., Kephalopoulos, S., and Jantunen, M.: A review of source apportionment techniques and marker substances available for identification of personal exposure, indoor and outdoor sources of chemicals, EUR 22349 EN; JRC - European Commission, 2006.

Bukowiecki, N., Lienemann, P., Hill, M., Figi, R., Richard, A., Furger, M., Rickers, K., Falkenberg, G., Zhao, Y., Cliff, S. S., Prévôt, A. S. H., Baltensperger, U., Buchmann, B., and Gehrig, R.: Real-world emission factors for antimony and other brake wear related trace elements: Size-segregated values for light and heavy duty vehicles, Environ. Sci. Tech., 43(21), 8072-8078, 2009.

Bukowiecki, N., Lienemann, P. , Hill, M., Furger, M., Richard, A., Amato, F., Prévôt, A. S. H., Baltensperger, U., Buchmann B., and Gehrig, R.: PM 10 emission factors for non-exhaust particles generated by road traffic in an urban street canyon and along a freeway in Switzerland, Atmos. Environ., 44(19), 2330-2340, 2010.

Cavalli, F., Viana, M., Yttri, K. E., Genberg, J., and Putaud, J.P.: Toward a standardised thermal-optical protocol for measuring atmospheric organic and elemental carbon: the EUSAAR protocol, Atmos. Meas. Tech., 3, 79-89, doi:10.5194/amt-3-79-2010, 2010.

Chiari, M., Lucarelli, F., Mazzei, F., Nava, S., Paperetti, L., Prati, P., Valli, G., and Vecchi, R.: Characterization of airborne particulate matter in an industrial district near Florence by PIXE and PESA, X-Ray Spectrom., 34(4), 323-329, 2005.

Dall'Osto, M., Harrison, R. M., Coe, H., Williams, P. I., and Al- 
lan, J. D.: Real time chemical characterization of local and regional nitrate aerosols, Atmos. Chem. Phys., 9, 3709-3720, doi:10.5194/acp-9-3709-2009, 2009.

de Gouw, J. A., Welsh-Bon, D., Warneke, C., Kuster, W. C., Alexander, L., Baker, A. K., Beyersdorf, A. J., Blake, D. R., Canagaratna, M., Celada, A. T., Huey, L. G., Junkermann, W., Onasch, T. B., Salcido, A., Sjostedt, S. J., Sullivan, A. P., Tanner, D. J., Vargas, O., Weber, R. J., Worsnop, D. R., Yu, X. Y., and Zaveri, R.: Emission and chemistry of organic carbon in the gas and aerosol phase at a sub-urban site near Mexico City in March 2006 during the MILAGRO study, Atmos. Chem. Phys., 9, 3425-3442, doi:10.5194/acp-9-3425-2009, 2009.

DGT (Dirección General de Tráfico, National Roadside Traffic Statistics Department), available at: www.dgt.es., 2011.

EEA CSI 004-Exceedance of air quality limit values in urban areas (version 2), available at: http://themes.eea. europa.eu/IMS/IMS/ISpecs/ISpeci?cation20080701123452/ IAssessment1243521792257/view_content, 2009.

Escudero, M., Castillo, S., Querol, X., Avila, A., Alarcón, M., Viana, M. M., Alastuey, A., Cuevas, E., and Rodríguez, S.: Wet and dry African dust episodes over eastern Spain, J. Geophy. Res., 110, D18S08, doi:10.1029/2004JD004731, 2005.

Formenti, P., Prati, P., Zucchiatti, A., Lucarelli, F., and Mandó, P. A.: Aerosol study in the town of Genova with a PIXE analysis, Nucl. Instrum. Meth., 113, 359-362, 1996.

Gietl, J. K., Lawrence, R., Thorpe, A. J., and Harrison, R. M.: Identification of brake wear particles and derivation of a quantitative tracer for brake dust at a major road. Atmos. Environ., 44(2), 141-146, 2010.

Harrison, R. M. and Yin, J.: Particulate matter in the atmosphere: Which particle properties are important for its effects on health?, Sci. Total Environ., 249(1-3), 85-101, 2000.

Harrison, R. M. and Yin, J.: Sources and processes affecting carbonaceous aerosol in central England, Atmos. Environ. 42, 1413-1423, 2008.

Harrison, R. M., Jones, A. M., and Barrowcliffe, R.: Field study of the influence of metorological factors and traffic volumes upon suspended particle mass at urban roadside sites of differing geometries, Atmos. Environ., 38, 6361-6369, 2004.

Hoek, G., Fischer, P., Van Den Brandt, P., Goldbohm, S., and Brunekreef, B.: Estimation of long-term average exposure to outdoor air pollution for a cohort study on mortality, J. Expo. Anal. Env. Epid., 11(6), 459-469, 2001.

Hoffman, B., Moebus, S., Dragano, N., Stang, A., Möhlenkamp, S., Schmermund, A., Memmesheimer, M., Bröcker-Preuss, M., Mann, K., Erbel, R., and Jöckel, K. H.: Chronic residential exposure to particulate matter air pollution and systemic inflammatory markers, Environ. Health. Persp., 117(8), 1302-1308, 2009.

Jimenez, P., Lelieveld, J., and Baldasano, J. M.: Multiscale modeling of air pollutants dynamics in the northwestern Mediterranean basin during a typical summertime episode, J. Geophys. Res., 111, D18306, doi:10.1029/2005JD006516, 2006.

Jimenez, J. L., Canagaratna, M. R., Donahue, N. M., Prévôt, A. S. H., Zhang, Q., Kroll, J. H., DeCarlo, P. F., Allan, J. D., Coe, H., Ng, N. L., Aiken, A. C., Docherty, K. S., Ulbrich, I. M., Grieshop, A. P., Robinson, A. L., Duplissy, J., Smith, J. D., Wilson, K. R., Lanz, V. A., Hueglin, C., Sun, Y. L., Tian, J., Laaksonen, A., Raatikainen, T., Rautiainen, J., Vaattovaara, P., Ehn, M., Kulmala, M., Tomlinson, J. M., Collins, D. R., Cubison, M.
J., Dunlea, E. J., Huffman, J. A., Onasch, T. B., Alfarra, M. R., Williams, P. I., Bower, K., Kondo, Y., Schneider, J., Drewnick, F., Borrmann, S., Weimer, S., Demerjian, K., Salcedo, D., Cottrell, L., Griffin, R., Takami, A., Miyoshi, T., Hatakeyama, S., Shimono, A., Sun, J. Y., Zhang, Y. M., Dzepina, K., Kimmel, J. R., Sueper, D., Jayne, J. T., Herndon, S. C., Trimborn, A. M., Williams, L. R., Wood, E. C., Middlebrook, A. M., Kolb, C. E., Baltensperger, U., and Worsnop, D. R.: Evolution of Organic Aerosols in the Atmosphere, Science, 326(5959), 1525-1529, 2009.

Oliveira, C., Pio, C., Caseiro, A., Santos, P., Nunes, T., Mao, H., Luahana, L., and Sokhi, R.: Road traffic impact on urban atmospheric aerosol loading at Oporto, Portugal, Atmos. Environ., 44(26), 3147-3158, 2010.

Pacyna, J. M.: Source-receptor relationships for trace elements in Northern Europe, Water Air Soil Poll., 30(3-4), 825-835, 1986.

Pandolfi, M., Querol, X., Alastuey, A., Jimenez, J. L., Cusack, M., Reche, C., Pey, J., Mohr, C., DeCarlo, P., Prévôt, A., Baltensperger, U., Artiñano, B., Baldasano, J.M., Jorba, O., Burkhart, J., Hansel, A., Schallhart, S., Müller, M., Metzger, A., Ortega, A., Saarikoski, S., Cubison, M., Ng S., Lorente, J., Nemitz, E., di Marco, C., Peñuelas, J., Sicard, M., Comeron, A., Amato, F., Moreno, T., Viana, M., Pérez, N., Moreno, N., Seco, R., Filella, I., Llusià, J., Piot, M., Pay, M. T. Source and origin of PM in the Western Mediterranean Basin: An overview of the DAURE campaign, Atmos. Chem. Phys. Discuss., in preparation, 2010.

Pey, J., Rodríguez, S., Querol, X., Alastuey, A., Moreno, T., Putaud, J. P., and Van Dingenen, R.: Variations of urban aerosols in the western Mediterranean, Atmos. Environ., 42(40), 9052-9062, 2008.

Perez, N., Pey, J., Querol, X., Alastuey, A., Lopez, J. M., Viana, M.: Partitioning of major and trace components in $\mathrm{PM}_{10}, \mathrm{PM}_{2.5}$ and $\mathrm{PM}_{1}$ at an urban site in Southern Europe, Atmos. Environ., 42, 1677-1691, 2008.

Querol, X., Alastuey, A., Rodríguez, S., Plana, F., Ruiz, C.R., Cots, N., Massagué, G., and Puig, O.: $\mathrm{PM}_{10}$ and $\mathrm{PM}_{2.5}$ source apportionment in the Barcelona metropolitan area, Catalonia, Spain, Atmos. Environ., 35, 6407-6419, 2001a.

Querol, X., Alastuey, A., Rodríguez, S., Plana, F., Mantilla, E., and Ruiz, C. R.: Monitoring of $\mathrm{PM}_{10}$ and $\mathrm{PM}_{2.5}$ around primary particulate anthropogenic emission sources. Atmos. Environ., 35, 845-858, 2001b.

Querol, X., Alastuey, A., Ruiz, C. R., Artiñano, B., Hansson, H. C., Harrison, R. M., Buringh, E., Brink, H. M. T., Lutz, M., Bruckmann, P., Straehl, P., and Schneider, J.: Speciation and origin of $\mathrm{PM}_{10}$ and $\mathrm{PM}_{2.5}$ in selected European cities, Atmos. Environ., 38, 6547-6555, 2004.

Querol, X., Pey, J., Pandolfi, M., Alastuey, A., Cusack, M., Perez, N., Moreno, T., Viana, M., Mihalopoulos, N., Kallos, G., and Kleanthous S.: African dust contributions to mean ambient $\mathrm{PM}_{10}$ mass-levels across the Mediterranean Basin, Atmos. Environ., 43(28), 4266-4277, 2009.

Richard, A., Bukowiecki, N., Lienemann, P., Furger, M., Fierz, M., Minguillón, M. C., Weideli, B., Figi, R., Flechsig, U., Appel, K., Prévôt, A. S. H., and Baltensperger, U.: Quantitative sampling and analysis of trace elements in atmospheric aerosols: impactor characterization and Synchrotron-XRF mass calibration, Atmos. Meas. Tech., 3, 1473-1485, doi:10.5194/amt-3-1473- 
2010, 2010.

Rodríguez, S., Cuevas, E., González, Y., Ramos, R., Romero, P. M., Perez, N., Querol, X., and Alastuey, A.: Influence of sea breeze circulation and road traffic emissions on the relationship between particle number, black carbon, $\mathrm{PM}_{1}, \mathrm{PM}_{2.5}$ and $\mathrm{PM}_{2.5}-$ 10 concentrations in a coastal city, Atmos. Environ., 42, 65236534, 2008.

Snyder, D. C., Rutter, A. P., Worley, C., Olson, M., Plourde, A., Bader, R. C., Dallmann, T., and Schauer, J. J.: Spatial variability of carbonaceous aerosols and associated source tracers in two cites in the Midwestern United States, Atmos. Environ., 44(13), 1597-1608, 2010.

Sternbeck, J., Sjödin, A., and Andreasson, K.: Metal emissions from road traffic and the influence of resuspension - -results from two tunnel studies, Atmos. Environ. 36, 4735-4744, 2002.
Turpin, B. J. and Huntzicker, J. J.: Identification of secondary organic aerosol episodes and quantisation of primary and secondary organic aerosol concentrations during SCAQS, Atmos. Environ., 29, 3527-3544, 1995.

USEPA: Health Assessment Document for Diesel Engine Exhaust. EPA/600/8-90/057F. National Center for Environmental Assessment, Washington, DC, 2002.

Viana, M., Kuhlbusch, T. A. J., Querol, X., Alastuey, A., Harrison, R. M., Hopke, P. K., Winiwarter, W., Vallius, M., Szidat, S., Prévôt, A. S. H., Hueglin, C., Bloemen, H., Wåhlin, P., Vecchi R., Miranda, A. I., Kasper-Giebl, A., Maenhaut, W., and Hitzenberger R.: Source apportionment of particulate matter in Europe: A review of methods and results, J. Aerosol Sci., 39(10), 827849, 2008. 